\title{
Natural Antimicrobials and Oral Microorganisms: A Systematic Review on Herbal Interventions for the Eradication of Multispecies Oral Biofilms
}

\author{
Lamprini Karygianni ${ }^{1 *}$, Ali Al-Ahmad ${ }^{1}$, Aikaterini Argyropoulou ${ }^{2}$, Elmar Hellwig ${ }^{1}$, \\ Annette C. Anderson ${ }^{1}$ and Alexios L. Skaltsounis ${ }^{2}$
}

OPEN ACCESS

Edited by:

Yuji Morita,

Aichi Gakuin University, Japan

Reviewed by:

Yixin Shi,

Arizona State University, USA

Rahman Md. Habiur,

Rajshahi University, Bangladesh

*Correspondence:

Lamprini Karygianni lamprini.karygianni@ uniklinik-freiburg.de

Specialty section: This article was submitted to Antimicrobials, Resistance and Chemotherapy,

a section of the journal

Frontiers in Microbiology

Received: 22 September 2015 Accepted: 18 December 2015

Published: 14 January 2016

Citation: Karygianni L, Al-Ahmad A,

Argyropoulou A, Hellwig E, Anderson AC and Skaltsounis AL (2016) Natural Antimicrobials and Oral Microorganisms: A Systematic Review on Herbal Interventions for the Eradication of Multispecies Oral Biofilms. Front. Microbiol. 6:1529. doi: 10.3389/fmicb.2015.01529
${ }^{1}$ Department of Operative Dentistry and Periodontology, Center for Dental Medicine, University of Freiburg, Freiburg, Germany, ${ }^{2}$ Department of Pharmacognosy and Natural Product Chemistry, Faculty of Pharmacy, National and Kapodistrian University of Athens, Athens, Greece

Oral diseases such as caries and periodontitis are mainly caused by microbial biofilms. Antibiotic therapy has reached its limits with regard to antimicrobial resistance, and new therapeutic measures utilizing natural phytochemicals are currently a focus of research. Hence, this systematic review provides a critical presentation of the antimicrobial effects of various medicinal herbs against in vitro, ex vivo, and in situ formed multispecies oral biofilms. Searches were performed in three English databases (PubMed, EMBASE, CAMbase) and the electronic archives of five German journals from the times of their establishment until October 10th, 2014, with the search terms "(plant extracts OR herbal extracts OR plant OR herb) AND (oral biofilm OR dental biofilm OR dental plaque OR oral disease OR dental disease)." The pooled data were assessed according to Preferred Reporting Items for Systematic Reviews and Meta-Analyses guidelines (PRISMA). Initially, 1848 articles were identified, out of which 585 full-text articles were screened, 149 articles were reevaluated for eligibility and finally, 14 articles met all inclusion criteria. The data of 14 reports disclosed enhanced antiadhesive and antibiofilm activity by the plant extracts obtained from Vitis vinifera, Pinus spp., Coffea canephora, Camellia sinensis, Vaccinium macrocarpon, Galla chinensis, Caesalpinia ferrea Martius, Psidium cattleianum, representative Brazilian plants and manuka honey. Overall, a positive correlation was revealed between herb-based therapies and elimination rates of all types of multispecies oral biofilms. In that context, integrating or even replacing conventional dental therapy protocols with herbal-inspired treatments can allow effective antimicrobial control of oral biofilms and thus, dental diseases.

Keywords: plant extracts, medicinal herbs, multispecies oral biofilms, antiadhesive and antimicrobial properties, oral diseases 


\section{INTRODUCTION}

An important trend in microbiological dental research recently is the discovery of new methods to eradicate dental plaque biofilms. It is well-known that the transition of "healthy" oral biofilms into pathological ones is etiologically associated with dental diseases, e.g., caries, periodontitis, or periimplantitis (Madianos et al., 2005). Interestingly, an estimated 700 bacterial species, embedded in extracellular polysaccharide-rich matrix, have been found to dwell within multispecies oral biofilms (Figure 1) (Achtman and Wagner, 2008; Koo et al., 2013; Nikitkova et al., 2013). The "battle" against oral biofilms is a very challenging task, mainly due to their tendency to persist in spite of treatment. This tendency has been attributed to numerous cell-cell communication pathways such as quorumsensing, horizontal gene transfer, and intrabiofilm metabolic transaction (Kolenbrander et al., 2010). Consequently, biofilm microorganisms can be up to 1000 times more resistant than planktonic bacteria to conventional antimicrobial therapies with antibacterial agents such as antibiotics or chlorhexidine (Welin-Neilands and Svensäter, 2007; Karygianni et al., 2014b).
Meanwhile, the ineffectiveness of antibiotics against several microorganisms e.g., methicillin-resistant Staphylococcus aureus (MRSA) and vancomycin-resistant enterococci (VRE) is a growing threat in the field of oral health (Smith et al., 2013). The recovery of genes associated with antibiotic resistance to erythromycin, tetracycline, and beta-lactamase from infected root canals also underlines the therapeutic barriers of antimicrobial treatment in dental infections (Rôças and Siqueira, 2013; Al-Ahmad et al., 2014). Finally, the presence of intra- or inter-individual discrepancies challenges the elimination of oral biofilm communities (Al-Ahmad et al., 2007).

In view of the growing ineffectiveness of conventional oral biofilm eradication, the implementation of novel treatments inspired by nature has lately gained increasing interest. The wise statement of Hippocrates "Nature itself is the best physician" has now been updated to include the beneficial influences from the plant kingdom against biofilm-related dental diseases. To date, numerous natural plant extracts have been screened for antimicrobial activity against planktonic and biofilm microorganisms (Groppo et al., 2008; Ramakrishna et al., 2011; Sofrata et al., 2011; Paddon et al., 2013). However, over 300.000
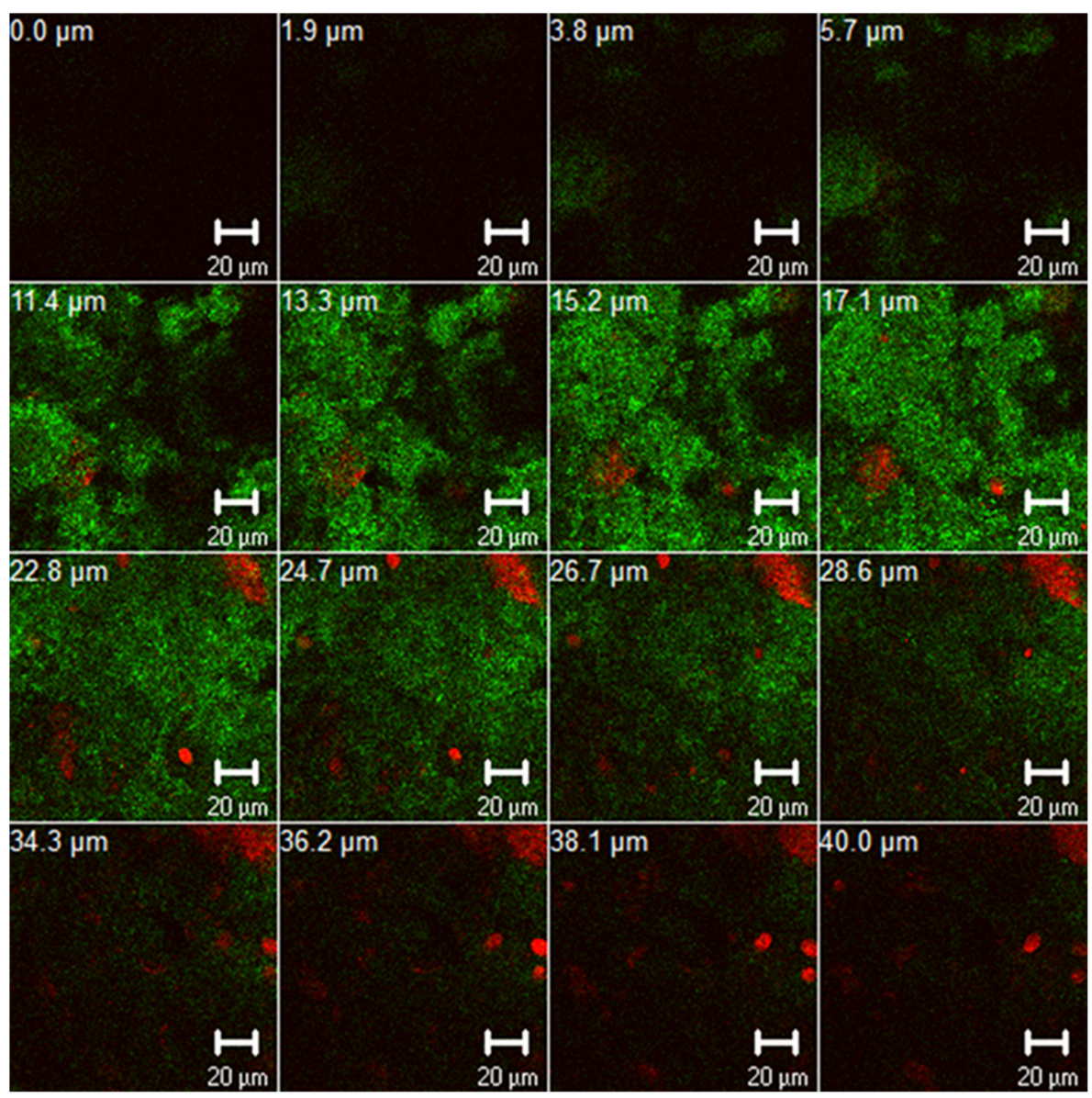

FIGURE 1 | Z-section gallery of representative confocal laser scanning microscopic (CLSM) image illustrating 3-day old oral biofilm after live/dead staining. The panel depicts live (green) and dead (red) biofilm microorganisms and contains multiple Z-sections induced by vertical sectioning in $1.9 \mu \mathrm{m}$ intervals through the oral biofilm above the substratum. Scale bar, $20 \mu \mathrm{m}$. 
herbs still need to be examined with regard to their potential for antimicrobial activity (Ngo et al., 2013). Despite the fact that numerous reports on the antimicrobial effectiveness of various medicinal herbs against planktonic microorganisms and monospecies oral biofilms have been published in the literature, a summary of information about their effects on multispecies oral biofilms is not available. Therefore, the aim of the present systematic review was to qualitatively summarize the antimicrobial activity of several medicinal herbs against in vitro, ex vivo and in vivo formed multispecies oral biofilms. To the best of our knowledge, this is the first systematic review of the application of various natural extracts against multispecies oral biofilms.

\section{MATERIAL AND METHODS}

\section{Search Strategy}

In order to find suitable articles, the following electronic databases were searched from the times of their establishment until 10th October, 2014: PubMed, EMBASE, CAMbase, and the electronic archives of the journals "Zeitschrift für klassische Homöopathie," "Erfahrungsheilkunde," "Zeitschrift für Phytotherapie," "Allgemeine Homöopathische Zeitung," and "Pharmazeutische Zeitung online." The search terms for papers associated with herbal extracts and oral biofilms were divided in two groups: intervention (plant extracts OR herbal extracts OR plant OR herb) and condition (oral biofilm OR dental biofilm OR dental plaque OR oral disease OR dental disease). The groups of terms listed above were matched to give 15 different search term combinations. Furthermore, related reviews were considered as an additional source of literature reports. Subsequently, the resulting literature reports were formatted and imported into a mutual Endnote library for all of the searched databases. After the insertion of all relevant combinations in Endnote, all duplicates were automatically removed by the program.

\section{Inclusion Criteria}

Herbal interventions were characterized as plant-derived preparations (extracts or fractions) emanating from roots, bulbs, trunks, leaves, seeds, flowers and fruits that were applied against oral biofilms worldwide. In this review in vitro, in situ, and ex vivo studies which investigated the impact of the aforementioned preparations on in vitro, ex vivo, and in situ formed multispecies oral biofilms were included. Among the latter, only the ones which were comprised of at least two microbial species could be defined as multispecies and were studied in this review. Only microbial biofilms which consisting of representative oral microorganisms were reviewed. Studies published in both English and German were taken into consideration.

\section{Exclusion Criteria}

Purified compounds and essential oils originating from plants were excluded from this study. Reports omitted from this review included randomized controlled trials (RCTs), as well as all other types of clinical studies. Studies not relating to oral biofilms or referring to monospecies oral biofilms were filtered out of this review. Furthermore, reports on the influence of various plant extracts against planktonic microorganisms, even if they were representative of the oral cavity, were not taken into account. Studies combining herbal interventions and routine pharmacologic therapy, e.g., antibiotics allowed for a co-intervention, were not reviewed.

\section{Study Selection}

The primary literature research was performed by one author. Afterwards, the resulting titles and abstracts were reevaluated by two independent authors, who were responsible for discarding reports unrelated to the subject according to the established inclusion and exclusion criteria. After this second screening round, the remaining studies were downloaded as full-text articles and were subsequently assessed for eligibility. If full access to the papers was impossible, these studies were excluded at this time point. Finally, irrelevant full-text articles were removed during the last third screening phase against the aforementioned criteria and the studies included in qualitative synthesis were determined.

\section{Data Organization}

A standard document was used to organize the information gained from each study. In particular, comprehensive data about the authors, year of publication, type of study, type of herbal intervention, extract concentration, treatment duration, type of multispecies biofilm, types of oral microorganisms within the biofilm, duration of incubation until biofilm formation, number of tested samples, methodological aspects, major outcomes, and limitations were noted. Additional clarification using terms from the listed final data was obtained by the dental library of the University of Freiburg and all other authors of the review with expertise in relevant scientific fields. To ensure the credibility of the extracted lists, the selected full texts were controlled twice. In cases of incongruity, the data were adjusted to the content of the source reports. Due to the heterogeneity of the selected reports, they were further classified into (a) in vitro, (b) ex vivo, and (c) in situ studies.

\section{Data Quality Evaluation}

The collected data were evaluated according to the Preferred Reporting Items for Systematic Reviews and Meta-Analyses guidelines (PRISMA; Liberati et al., 2009). The latter constitutes an updated version of the statement about the Quality of Reporting of Meta-analyses standards (QUOROM) developed by the QUOROM group. The PRISMA website (http://www. prisma-statement.org/statement.htm) contains the current form of the PRISMA statement. In particular, PRISMA includes an evidence-based set of practical tools, such as a detailed 27point checklist and a flowchart which supports the classification of the search strategy, study selection, and data assessment process in four stages. The aim of this quality control tool is to aid in literature screening, data extraction, and management and thus, enhance critical evaluation of a wide spectrum of research projects, e.g., randomized clinical trials and other types of intervention reports. To eliminate incongruity the 
aforementioned processes (data organization and quality) were finally surveyed by a second independent author.

\section{RESULTS}

\section{Description of Selected Reports}

Figure 2 depicts an overview of the study selection procedure. Out of a total number of 1848 articles identified after searching in three different English databases and the electronic archives of five German journals, 585 full-text articles were screened upon removal of duplicates. Afterwards, a total of 436 articles that did not meet the inclusion criteria were excluded and 149 full-text articles were reassessed for eligibility. Finally, after this second screening process 135 articles were excluded according to the aforementioned inclusion criteria and 14 of the reports were considered suitable for this review (Yamanaka et al., 2007; Alviano et al., 2008; Furiga et al., 2008, 2014; Hannig et al., 2008,
2009; Xie et al., 2008; Sampaio et al., 2009; Antonio et al., 2011, 2012; Badet and Quero, 2011; Brighenti et al., 2012; Meckelburg et al., 2014; Muñoz-Gonzalez et al., 2014). All 14 selected reports were found in English language databases from the time of their establishment until 10th October, 2014. Further details on each study regarding methodological and outcome aspects are summarized in Tables 2-4. All selected studies were written in English and involved treatment of in vitro, ex vivo and in situ formed multispecies oral biofilms with different plant extracts. The extract treatments were applied with a duration time ranging from 1 min (Furiga et al., 2008, 2014; Hannig et al., 2008, 2009; Xie et al., 2008; Sampaio et al., 2009; Antonio et al., 2011; Brighenti et al., 2012; Meckelburg et al., 2014) to $64 \mathrm{~h}$ (Badet and Quero, 2011). In terms of the medicinal herbs, four studies reported the effects of Vitis products and by-products, red wine, and/or grape seed extracts on multispecies oral biofilms (Furiga et al., 2008, 2014; Hannig et al., 2009; Muñoz-Gonzalez et al., 2014), three studies highlighted the anti-biofilm properties of

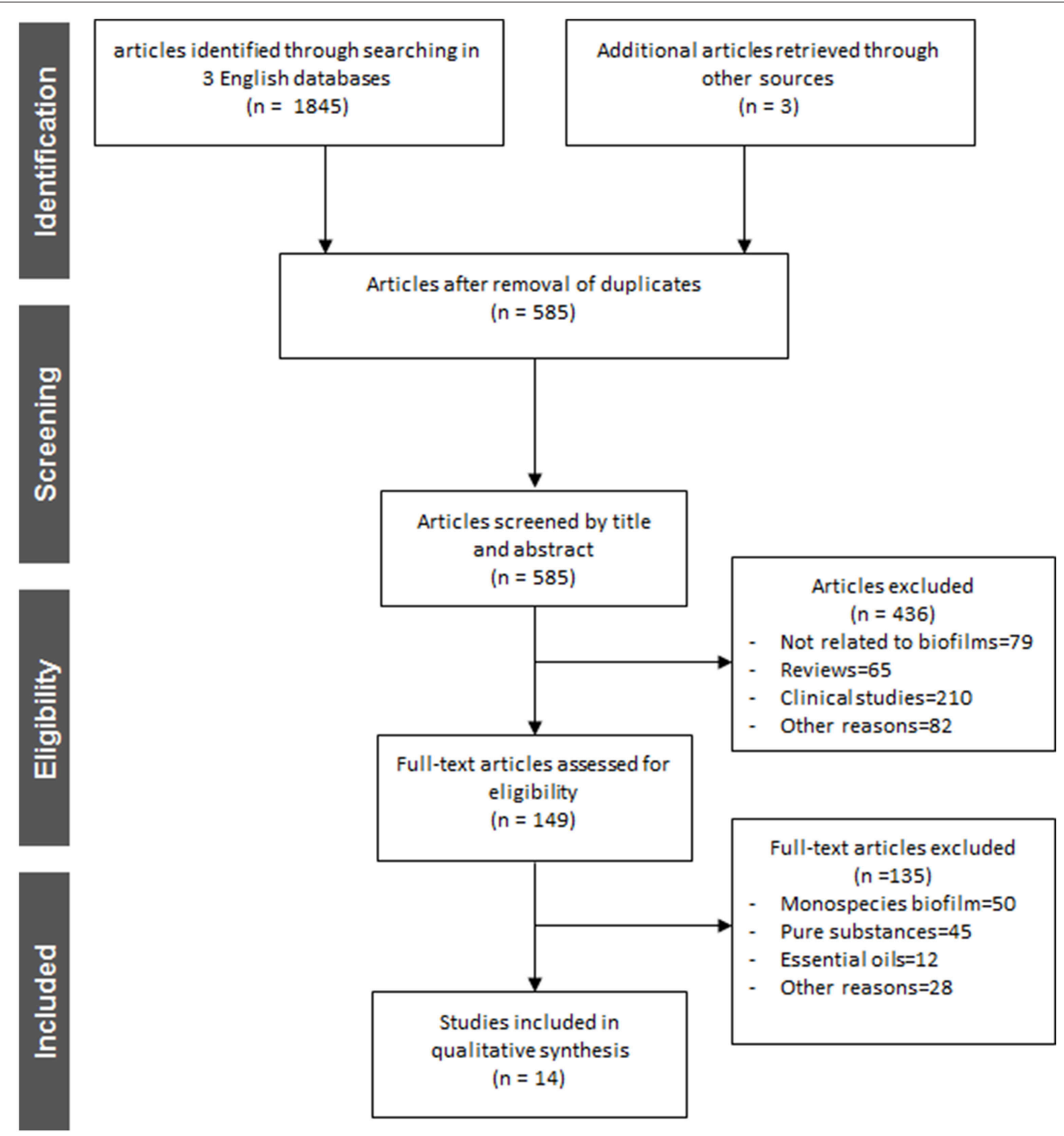

FIGURE 2 | Flowchart of the search strategy, study selection, and data management procedure. 
Coffea canephora extracts (Antonio et al., 2011, 2012; Meckelburg et al., 2014) two studies focused on the antimicrobial traits of tea (black tea, green tea, cistus tea; Hannig et al., 2008, 2009) and one study reported the high antimicrobial efficacy of Chinese galls (Xie et al., 2008) Individual reports on the antibiofilm activity of cranberry juice concentrate (Yamanaka et al., 2007), manuka honey (Badet and Quero, 2011), Caesalpinia ferrea Martius fruit extracts (Sampaio et al., 2009), Psidium cattleianum leaf extract (Brighenti et al., 2012), and Brazilian plant extracts (Alviano et al., 2008) were also taken into consideration.

To enhance understanding of their great bactericidal potential in the dental field, the most characteristic medicinal herbs with well-established antimicrobial activity against oral microorganisms (planktonic, adherent) are listed below. Table 1 constitutes an overview of the most representative herbs which have already been studied and acknowledged worldwide for their antimicrobial behavior against oral microorganisms.

\section{Herbal Interventions on In vitro Formed Multispecies Oral Biofilms}

Table 2 summarizes the herbal treatments on in vitro formed multispecies oral biofilms. A total of seven studies described the effects of several natural extracts on artificial multispecies oral biofilms prepared in the laboratory in vitro (Yamanaka et al., 2007; Furiga et al., 2008, 2014; Xie et al., 2008; Sampaio et al., 2009; Badet and Quero, 2011; MuñozGonzalez et al., 2014). The use of honey for treating microbial infections dates back to ancient times. Badet et al. revealed the beneficial effects of manuka honey extract $(50-500 \mu \mathrm{g} / \mathrm{ml})$, a monofloral honey produced in New Zealand

TABLE 1 | Overview of the representative plant extracts found to have favorable antimicrobial properties against oral bacteria.

\begin{tabular}{|c|c|c|}
\hline Name of plant extract & Tested oral microorganisms & Literature report \\
\hline Azadirachta indica (Neem sticks) & Streptococcus spp. & Wolinsky et al., 1996 \\
\hline Camellia sinensis (tea plant) & Streptococcus mutans, Streptococcus sobrinus & $\begin{array}{l}\text { Hamilton-Miller, 2001; } \\
\text { Yoshinaga et al., } 2014\end{array}$ \\
\hline Coffea arabica or canephora (coffee) & Streptococcus spp. & Ferrazzano et al., 2009 \\
\hline Humulus lupulus (hop plant) & Streptococcus spp. & Shinada et al., 2007 \\
\hline Vaccinium macrocarpon (cranberry) & Streptococcus spp., Porphyromonas gingivalis & Yamanaka et al., 2004, 2007 \\
\hline Punica granatum (pomegranate) & $\begin{array}{l}\text { Streptococcus spp., Candida albicans, Porphyromonas gingivalis, } \\
\text { Aggregatibacter actinomycetemcomitans, Prevotella intermedia }\end{array}$ & $\begin{array}{l}\text { de Oliveira et al., 2013; Howell } \\
\text { and D'Souza, } 2013\end{array}$ \\
\hline Salvadora persica (miswak) & $\begin{array}{l}\text { Porphyromonas gingivalis, Aggregatibacter actinomycetemcomitans, } \\
\text { Haemophilus influenzae }\end{array}$ & Sofrata et al., 2007 \\
\hline Theobroma cacao (cacao tree) & Streptococcus mutans, Streptococcus sanguinis & Percival et al., 2006 \\
\hline Vitis vinifera (grape vine) & Actinomyces oris, Fusobacterium nucleatum, Streptococcus oralis & Muñoz-Gonzalez et al., 2014 \\
\hline Myristica fragrans (nutmeg) & $\begin{array}{l}\text { Streptococcus spp., Aggregatibacter actinomycetemcomitans, } \\
\text { Porphyromonas gingivalis, Fusobacterium nucleatum }\end{array}$ & Shafiei et al., 2012 \\
\hline Morus alba (white mulberry) & Streptococcus mutans & Islam et al., 2008 \\
\hline Eucalyptus globulus (eucalyptus leaves) & Porphyromonas gingivalis & Nagata et al., 2006 \\
\hline Curcuma xanthorrhiza (Javanese ginger) & Streptococcus mutans & Kim et al., 2008 \\
\hline Arctium lappa (greater burdock) & Enterococcus faecalis, Candida albicans & Pereira et al., 2005 \\
\hline Mikania laevigata (guaco) & Streptococcus spp. & Yatsuda et al., 2005 \\
\hline Inula viscosa (false yellowhead) & Porphyromonas gingivalis, Streptococcus sobrinus, Enterococcus faecalis & Karygianni et al., 2014a \\
\hline Allium sativum (garlic) & $\begin{array}{l}\text { Streptococcus spp., Enterococcus faecalis, Prevotella intermedia, } \\
\text { Fusobacterium nucleatum }\end{array}$ & $\begin{array}{l}\text { Bakri and Douglas, 2005; Lee } \\
\text { et al., } 2011\end{array}$ \\
\hline Hyptis divaricata (propolis) & Streptococcus mutans, Lactobacillus spp. & Dziedzic et al., 2013 \\
\hline Helichrysum italicum (curry plant) & Streptococcus mutans & Nostro et al., 2004 \\
\hline Pistacia lentiscus (mastic gum) & Porphyromonas gingivalis, Prevotella intermedia, Fusobacterium nucleatum & Karygianni et al., 2014a \\
\hline Aloe vera & $\begin{array}{l}\text { Streptococcus mutans, Aggregatibacter actinomycetemcomitans, } \\
\text { Porphyromonas gingivalis, Bacteroides fragilis }\end{array}$ & Fani and Kohanteb, 2012 \\
\hline Coriandrum sativum (coriander) & Candida albicans & Furletti et al., 2011 \\
\hline Acacia nilotica (babul) & mutans streptococci & Gupta and Gupta, 2015 \\
\hline Hibiscus sabdariffa (roselle) & Streptococcus mutans & Afolabi et al., 2008 \\
\hline Mangifera indica (mango) & Prevotella intermedia, Porphyromonas gingivalis & Bairy et al., 2002 \\
\hline Citrus limonum (lemon) & Candida albicans, Enterococcus faecalis & Oliveira et al., 2014 \\
\hline Cinnamomum zeylanicum (ceylon cinnamon) & Actinomyces naes/undii, Prevotella nigrescens, Streptococcus mutans & Bardají et al., 2015 \\
\hline Glycyrrhiza uralensis (Chinese liquorice) & Streptococcus mutans, Porphyromonas gingivalis & Villinski et al., 2014 \\
\hline Hypericum perforatum (St. John's Wort) & $\begin{array}{l}\text { Streptococcus mutans, Streptococcus sobrinus, Lactobacillus plantarum, } \\
\text { Enterococcus faecalis }\end{array}$ & Süntar et al., 2015 \\
\hline Origanum vulgare (oregano) & Streptococcus mutans, Candida albicans & Miller et al., 2015 \\
\hline
\end{tabular}


TABLE 2 | Overview of the names and concentrations of the medicinal herbs, bacterial characteristics of oral biofilms, treatment duration, and major outcomes of the studies of herbal intervention on in vitro formed multispecies oral biofilms.

\begin{tabular}{|c|c|c|c|c|c|}
\hline Authors & Year & $\begin{array}{l}\text { Name of medicinal } \\
\text { herb/concentration }\end{array}$ & Oral biofilm microorganisms & Treatment duration & Main results \\
\hline $\begin{array}{l}\text { Badet and Quero, } \\
2011\end{array}$ & 2011 & $\begin{array}{l}\text { Manuka honey } \\
\text { extract/50-500 } \mu \mathrm{g} / \mathrm{ml}\end{array}$ & $\begin{array}{l}\text { Streptococcus mutans ATCC } 25175 \\
\text { Streptococcus sobrinus ATCC } 33478 \\
\text { Lactobacillus rhamnosus ATCC } 7469 \\
\text { Porphyromonas gingivalis ATCC } 33277 \\
\text { Fusobacterium nucleatum ATCC } 10953\end{array}$ & $\begin{array}{l}\text { Incubation for } 64 \mathrm{~h} \\
\text { under aerobic } \\
\text { conditions }\end{array}$ & $\begin{array}{l}\text { - Manuka honey showed antiadhesive } \\
\text { properties at a concentration of } \\
200 \mu \mathrm{g} / \mathrm{ml} \\
\text { - Manuka honey presented antibiofilm } \\
\text { activity at a concentration of } \\
500 \mu \mathrm{g} / \mathrm{ml}\end{array}$ \\
\hline Furiga et al., 2008 & 2008 & $\begin{array}{l}\text { Red grape marc extract } \\
\text { (GME) } \\
\text { red wine extract (RWE) } \\
\text { pine bark extract } \\
(\mathrm{PBE}) / 50-2000 \mu \mathrm{g} / \mathrm{ml}\end{array}$ & $\begin{array}{l}\text { Streptococcus mutans ATCC } 25175 \\
\text { Streptococcus sobrinus ATCC } 33478 \\
\text { Lactobacillus rhamnosus ATCC } 7469 \\
\text { Porphyromonas gingivalis ATCC } 33277 \\
\text { Fusobacterium nucleatum ATCC } 10953\end{array}$ & $\begin{array}{l}\text { Treatments of } 1 \text { min } \\
\text { each, every } 4 \mathrm{~h} \text { over } \\
16 \mathrm{~h}\end{array}$ & $\begin{array}{l}\text { - Potency against bacterial viability: } \\
\text { chlorhexidine > RWE = PBE > GME } \\
\text { - GME inhibited the glass surface } \\
\text { adhesion by S. mutans } \\
\text { - GME and PBE inhibited bacterial } \\
\text { adhesion to hydroxyapatite } \\
\text { - PBE inhibited synthesis of } \\
\text { glucosyltransferase by } 83.9 \% \text { at } \\
100 \mu \mathrm{g} / \mathrm{ml}\end{array}$ \\
\hline Furiga et al., 2014 & 2014 & $\begin{array}{l}\text { Grape seed extract (GSE, } \\
2000 \mu \mathrm{g} / \mathrm{ml}) \\
\text { 3-pyridinemethanol } \\
\text { hydrofluoride }(10.2 \mathrm{mg} / \mathrm{ml})\end{array}$ & $\begin{array}{l}\text { Streptococcus mutans ATCC } 25175 \\
\text { Streptococcus sobrinus ATCC } 33478 \\
\text { Lactobacillus rhamnosus ATCC } 7469 \\
\text { Porphyromonas gingivalis ATCC } 33277 \\
\text { Fusobacterium nucleatum ATCC } 10953 \\
\text { Actinomyces viscosus }\end{array}$ & $\begin{array}{l}\text { Threefold exposure of } \\
1 \text { min, at } 4 \text {-h intervals, } \\
\text { twice a day over } 64 \mathrm{~h} \text {, } \\
\text { between treatments } \\
\text { biofilms were } \\
\text { incubated }\end{array}$ & $\begin{array}{l}\text { - The combination of GSE and } \\
\text { fluoride demonstrated the highest } \\
\text { antibiofilm effectiveness } \\
\text { - GSE and the combination of GSE } \\
\text { and fluoride inhibited } \\
\text { glucosyltransferase activity and } \\
\text { insoluble glucan synthesis by } 43.9 \\
\text { and } 65.7 \% \text {, respectively }\end{array}$ \\
\hline $\begin{array}{l}\text { Muñoz-Gonzalez } \\
\text { et al., } 2014\end{array}$ & 2014 & $\begin{array}{l}\text { Red wine, dealcoholized } \\
\text { red wine, red wine extract } \\
(1.6 \mathrm{~g} / \mathrm{l}) \text { enriched either } \\
\text { with grape seed extract } \\
(2.5 \mathrm{~g} / 100 \mathrm{ml}) \text { or inactive } \\
\text { dry yeast (IDY, } 0.4 \mathrm{~g} / \mathrm{l})\end{array}$ & $\begin{array}{l}\text { Actinomyces oris OMZ } 745 \\
\text { Fusobacterium nucleatum OMZ } 598 \\
\text { Streptococcus oralis OMZ } 607 \\
\text { Streptococcus mutans UA159 } \\
\text { Veillonella dispar ATCC } 17748\end{array}$ & $\begin{array}{l}\text { Treatments of } 2 \text { min } \\
\text { each, at } 7 \text {-h intervals, } \\
\text { twice a day over } 7 \\
\text { days }\end{array}$ & $\begin{array}{l}\text { - Red wine, dealcoholized red wine, } \\
\text { and red wine extract spiked with } \\
\text { grape seed extract decreased CFU } \\
\text { values of F. nucleatum and S. oralis } \\
\text { - Red wine extract spiked with IDY } \\
\text { reduced oral biofilm viability } \\
\text { - No degradation of the flavan-3-ol } \\
\text { and quercetin precursors was } \\
\text { observed. }\end{array}$ \\
\hline $\begin{array}{l}\text { Sampaio et al., } \\
2009\end{array}$ & 2009 & $\begin{array}{l}\text { Caesalpinia ferrea Martius } \\
\text { fruit } \\
\text { extracts } / 25-100 \mu \mathrm{g} / \mathrm{ml}\end{array}$ & $\begin{array}{l}\text { Candida albicans ATCC } 36232 \\
\text { Streptococcus mutans ATCC } 25175 \\
\text { Streptococcus salivarius ATCC } 7073 \\
\text { Streptococcus oralis ATCC } 10557 \\
\text { Lactobacillus casei ATCC } 7469\end{array}$ & $\begin{array}{l}\text { Treatments of } 1 \mathrm{~min} \\
\text { each, at } 16 \mathrm{~h} \text { and } \\
30 \mathrm{~min} \text {, and at } 40 \mathrm{~h} \\
\text { and } 30 \mathrm{~min} \text { over } 64 \mathrm{~h} \\
\text { and } 30 \mathrm{~min}\end{array}$ & $\begin{array}{l}\text { - Complete inhibition of biofilm } \\
\text { formation at } 10^{-5} \text { microbial dilution } \\
\text { - At } 10^{-4} \text { microbial dilution the } \\
\text { extract inhibited growth of } \mathrm{S} \text {. } \\
\text { mutans, and } \mathrm{C} \text {. albicans by } 0.5 \pm \\
0.1 \text {, and } 0.7 \pm 0.1 \times 10^{6} \mathrm{CFU} \text {, } \\
\text { respectively }\end{array}$ \\
\hline $\begin{array}{l}\text { Yamanaka et al., } \\
2007\end{array}$ & 2007 & $\begin{array}{l}\text { Cranberry juice } \\
\text { concentrate/250 or } \\
500 \mu \mathrm{g} / \mathrm{ml}\end{array}$ & $\begin{array}{l}\text { Porphyromonas gingivalis } \\
\text { Fusobacterium nucleatum }\end{array}$ & $\begin{array}{l}\text { Incubation for } 24 \mathrm{~h} \\
\text { under anaerobic } \\
\text { conditions }\end{array}$ & $\begin{array}{l}\text { - Cranberry extract hindered } \\
\text { synergistic biofilm formation } \\
\text { - Cranberry extract (10, } 100 \mu \mathrm{g} / \mathrm{ml}) \\
\text { hindered Arg-gingipain and } \\
\text { Lys-gingipain }\end{array}$ \\
\hline Xie et al., 2008 & 2008 & $\begin{array}{l}\text { Galla chinensis extracts } \\
(\mathrm{GCE}) / 4 \mathrm{mg} / \mathrm{ml}\end{array}$ & $\begin{array}{l}\text { Streptococcus sanguis ATCC10556 } \\
\text { Streptococcus mutans ATCC25175 } \\
\text { Actinomyces naeslundii WVU } 627 \\
\text { Lactobacillus rhamnosus AC } 413\end{array}$ & $\begin{array}{l}\text { Eight treatments of } \\
1 \text { min each, every } 12 \mathrm{~h} \\
\text { over } 5 \text { days }\end{array}$ & $\begin{array}{l}\text { - Higher planktonic phase pH values } \\
\text { - Lower total viable counts (CFU) after } \\
\text { GCE treatment } \\
\text { - CFU of S. sanguis and S. mutans } \\
\text { decreased } \\
\text { - Fluorescence images of GCE } \\
\text { treated biofilms with decreased } \\
\text { optical densities }\end{array}$ \\
\hline
\end{tabular}


TABLE 3 | Overview of the names and concentrations of the medicinal herbs, bacterial characteristics of oral biofilms, treatment duration, and major outcomes of studies on herbal interventions on ex vivo formed multispecies oral biofilms.

\begin{tabular}{|c|c|c|c|c|c|}
\hline Authors & Year & $\begin{array}{l}\text { Name of medicinal } \\
\text { herb/concentration }\end{array}$ & $\begin{array}{l}\text { Oral biofilm } \\
\text { microorganisms }\end{array}$ & Treatment duration & Main results \\
\hline $\begin{array}{l}\text { Alviano et al., } \\
2008\end{array}$ & 2008 & $\begin{array}{l}\text { Aqueous extracts from Cocos } \\
\text { nucifera (husk fiber, } \\
\text { coco-cravo), Ziziphus joazeiro } \\
\text { (innerbark, juazeiro), } \\
\text { Caesalpinia pyramidalis } \\
\text { (leaves, catingueira), and } \\
\text { alcoholic extract from } \\
\text { Aristolochia cymbifera (stem, } \\
\text { milhomen)/16 mg/ml }\end{array}$ & $\begin{array}{l}\text { Unstimulated human } \\
\text { whole mixed saliva }\end{array}$ & $\begin{array}{l}\text { Treatment for } 30 \mathrm{~min} \text {, } \\
\text { incubation under } \\
\text { anaerobic conditions } \\
\text { for } 48 \mathrm{~h}\end{array}$ & $\begin{array}{l}\text { - The alcoholic extract of } A \text {. cymbifera ( } 94.2 \%) \\
\text { and the aqueous extracts of } C \text {. pyramidalis } \\
\text { (72.8\%) and C. nucifera (64.1\%) reduced the } \\
\text { viable count of adherent bacteria } \\
\text { - The activity of the free radical } \\
\text { 1,1-diphenyl-2-picryl-hydrazyl- } \\
\text { hydrate (DPPH) was mostly affected by the } \\
\text { aqueous extracts from C. nucifera and C. } \\
\text { pyramidalis }\end{array}$ \\
\hline $\begin{array}{l}\text { Antonio et al., } \\
2011\end{array}$ & 2011 & $\begin{array}{l}\text { Aqueous coffee extract from } \\
\text { Coffea canephora/50 } / \mathrm{g} / \mathrm{ml}\end{array}$ & $\begin{array}{l}\text { Unstimulated human } \\
\text { whole mixed saliva }\end{array}$ & $\begin{array}{l}\text { Treatments of } 1 \text { min } \\
\text { each, every } 24 \text { h over } 7 \\
\text { days }\end{array}$ & $\begin{array}{l}\text { - No significant differences in } \mathrm{pH} \text { values after } \\
\text { treatment with the extract } \\
\text { - C. canephora aqueous extract induced a } \\
\text { 4-log decrease in CFU of } S \text {. mutans after } 3 \mathrm{~h} \\
\text { treatment }\end{array}$ \\
\hline $\begin{array}{l}\text { Antonio et al., } \\
2012\end{array}$ & 2012 & $\begin{array}{l}\text { Unsweetened and sweetened } \\
\text { aqueous coffee extracts from } \\
\text { Coffea canephora/20 mg/ml }\end{array}$ & $\begin{array}{l}\text { Unstimulated human } \\
\text { whole mixed saliva }\end{array}$ & $\begin{array}{l}\text { Treatment for } 30 \mathrm{~min} \text {, } \\
\text { incubation under } \\
\text { anaerobic conditions } \\
\text { for } 48 \mathrm{~h}\end{array}$ & $\begin{array}{l}\text { - Coffea canephora extract extract reduced } \\
\text { CFU values in ex vivo oral biofilms by } 15 \% \text {. } \\
\text { - Sucrose concentrations from } 5 \% \text { up to } 20 \% \\
\text { inhibited growth of biofilm bacteria }\end{array}$ \\
\hline $\begin{array}{l}\text { Meckelburg } \\
\text { et al., } 2014\end{array}$ & 2014 & $\begin{array}{l}\text { Aqueous coffee extract from } \\
\text { Coffea canephora } / 50 \mu \mathrm{g} / \mathrm{ml}\end{array}$ & $\begin{array}{l}\text { Unstimulated human } \\
\text { whole mixed saliva }\end{array}$ & $\begin{array}{l}\text { Treatments of } 1 \text { min } \\
\text { each, every } 24 \text { h over } 7 \\
\text { days }\end{array}$ & $\begin{array}{l}\text { - Treatment with coffee extract resulted in an } \\
\text { increase in calcium concentration after } 4 \text { and } \\
7 \text { days } \\
\text { - Treatment with coffee extract induced mineral } \\
\text { loss from the tooth surfaces up to } 30 \mu \mathrm{m} \text { in } \\
\text { depth }\end{array}$ \\
\hline
\end{tabular}

and Australia from the nectar of the Leptospermum scoparium (Myrtaceae) on biofilms consisting of Streptococcus mutans, Streptococcus sobrinus, Lactobacillus rhamnosus, Porphyromonas gingivalis, and Fusobacterium nucleatum after incubation for $64 \mathrm{~h}$ under aerobic conditions (Badet and Quero, 2011). Furiga et al. published two reports about the antibiofilm activities of various extracts obtained from Vitis vinifera (Vitaceae) against artificial oral biofilms mainly composed of S. mutans, S. sobrinus, L. rhamnosus, P. gingivalis, and F. nucleatum (Furiga et al., 2008, 2014). Apart from wine, which is the primary product derived from Vitis plants, research in recent years has focused on the by-products of wine production, such as stems, skins, and seeds, consolidating the observation that agro-industrial wastes are rich in healthy plant ingredients. Red and white grapes originate from the plant $V$. vinifera and are polyphenol-rich sources of hydroxybenzoic acids (ellagic-, gallic-, syringic-, and vanillic acid), hydroxycinnamic acids (ferulic-, p-coumaric-, and caffeic acid), flavonols (catechin, epicatechin, kaempferol, myricetin), stilbenes (tyrosol), procyanidins, and anthocyanins (Furiga et al., 2008). Grapes possess antioxidant, antiinflammatory, antitumor, and antimicrobial properties (Bagchi et al., 2000). The latter include among others antiadhesive activities which can be primarily attributed to organic acids (van Loveren et al., 2012). In earlier reports on beneficial antibacterial effects of grapes and wines within the oral cavity, grapes showed high bactericidal activity against several oral microorganisms e.g., Actinomyces oris, F. nucleatum, and Streptococcus oralis (Furiga et al., 2008; Muñoz-Gonzalez et al., 2014).

In the first study of the group (Furiga et al., 2008), 1-min applications of red grape marc extract (GME) and red wine extract (RWE) in concentrations ranging from 50 to $2000 \mu \mathrm{g} / \mathrm{ml}$ at $4 \mathrm{~h}$-intervals over $16 \mathrm{~h}$ resulted in enhanced antiadhesive effects of GME, while RWE showed the highest antibacterial effects. In the second study of the same group (Furiga et al., 2014), grape seed extract (GSE, $2000 \mu \mathrm{g} / \mathrm{ml})$, either alone or enriched with 3-pyridinemethanol hydrofluoride, was incubated with biofilms containing the aforementioned microorganisms plus Actinomyces viscosus for $1 \mathrm{~min}$, at 4 -h intervals over $64 \mathrm{~h}$. The combination of GSE and fluoride exhibited the most antibiofilm properties and decreased glucosyltransferase activity as well as insoluble glucan synthesis by $65.7 \%$. Red wine (dealcoholized or not) and RWE (1.6 g/l) enriched either with grape seed extract $(2.5 \mathrm{~g} / 100 \mathrm{ml})$ or inactive dry yeast (IDY, $0.4 \mathrm{~g} / \mathrm{l}$ ) were also screened against in vitro formed multispecies biofilms (A. oris, F. nucleatum, Streptococcus oralis, S. mutans, Veillonella dispar) by another group (Furiga et al., 2014). The biofilms were treated for $2 \mathrm{~min}$ at 7 -h intervals over a period of 7 days. As a result, the total bacterial count of F. nucleatum and $S$. oralis were decreased by treatment with red wine and RWE enriched with grape seed. Furiga et al. also studied the effect of a pine bark extract (PBE) against artificial oral biofilms (Furiga et al., 2008). The authors do not mention the pine species used, since PBEs could derive from various 
TABLE 4 | Overview on the names and concentrations of the medicinal herbs, bacterial characteristics of oral biofilms, treatment duration, and major outcomes of the studies on herbal interventions on the in situ formed multispecies oral biofilms.

\begin{tabular}{|c|c|c|c|c|c|}
\hline Authors & Year & $\begin{array}{l}\text { Name of medicinal } \\
\text { herb/concentration }\end{array}$ & $\begin{array}{l}\text { Oral biofilm } \\
\text { microorganisms }\end{array}$ & Treatment duration & Main results \\
\hline $\begin{array}{l}\text { Brighenti } \\
\text { et al., } 2012\end{array}$ & 2012 & $\begin{array}{l}\text { Aqueous extract of Psidium } \\
\text { cattleianum leaf } \\
\text { extract } 167 \mathrm{mg} / \mathrm{ml}\end{array}$ & $\begin{array}{l}\text { Supragingival dental } \\
\text { plaque (palatal } \\
\text { appliance) }\end{array}$ & $\begin{array}{l}\text { Treatments of } 1 \mathrm{~min} \\
\text { each, at } 12 \text {-h intervals, } \\
\text { twice a day over } 14 \\
\text { days }\end{array}$ & $\begin{array}{l}\text { - The extract inhibited growth of biofilm bacteria } \\
\text { - No decrease in pH values after treatment with } \\
\text { the extract } \\
\text { - The extract reduced the total amount of } \\
\text { extracellular polysaccharides }\end{array}$ \\
\hline $\begin{array}{l}\text { Hannig et al., } \\
2008\end{array}$ & 2008 & Cistus tea/20 mg/ml & $\begin{array}{l}\text { Supragingival dental } \\
\text { plaque (individual upper } \\
\text { jaw splints) }\end{array}$ & $\begin{array}{l}\text { Pellicle formation for } \\
1 \text { min and } 15 \text { min, then } \\
10 \text {-min treatment, } \\
\text { splints kept in the oral } \\
\text { cavity for } 20 \text { min, } \\
40 \text { min, or } 109 \text { min }\end{array}$ & $\begin{array}{l}\text { - Cistus tea reduced the number of detectable } \\
\text { adherent bacteria } \\
\text { - Cistus tea caused decrease in peroxidase } \\
\text { activity after } 40 \text { min } \\
\text { - Glucosyltransferase, amylase, and lysozyme } \\
\text { activities remained unaffected }\end{array}$ \\
\hline $\begin{array}{l}\text { Hannig et al., } \\
2009\end{array}$ & 2009 & $\begin{array}{l}\text { Red wine, purple grape juice, } \\
\text { cistus tea, black tea, green } \\
\text { tea/10 mg/ml }\end{array}$ & $\begin{array}{l}\text { Supragingival dental } \\
\text { plaque (individual upper } \\
\text { jaw splints) }\end{array}$ & $\begin{array}{l}\text { Pellicle formation for } \\
1 \text { min, then 10-min } \\
\text { treatment, splints kept } \\
\text { in the oral cavity for } \\
\text { another } 19 \text { min or } \\
109 \text { min }\end{array}$ & $\begin{array}{l}\text { - All polyphenolic beverages reduced the } \\
\text { number of detectable adherent bacteria } \\
\text { - Confocal laser scanning microscopic images } \\
\text { showed no discrepancies in the organization } \\
\text { of bacterial aggregates } \\
\text { - Cistus tea, red wine, and grape juice caused a } \\
\text { decrease of up to } 66 \% \text { in oral biofilm bacteria }\end{array}$ \\
\hline
\end{tabular}

species, such as Pinus pinaster, Pinus maritima, Pinus radiata, Pinus massoniana. Proanthocyanidins are among the most abundant constituents in these extracts. Antiadhesive effects and high antibacterial potency of PBE were observed with 1-min applications in concentrations ranging from 50 to $2000 \mu \mathrm{g} / \mathrm{ml}$ at $4 \mathrm{~h}$-intervals over $16 \mathrm{~h}$. Interestingly, in the presence of $100 \mu \mathrm{g} / \mathrm{ml} \mathrm{PBE}$ glucosyltransferase synthesis decreased by 83.9\%. Sampaio et al. (2009) reported complete inhibition of multispecies biofilm formation for Candida albicans, S. mutans, Streptococcus salivarius, S. oralis, and Lactobacillus casei after 1min applications over $64 \mathrm{~h}$ and $30 \mathrm{~min}$ of $C$. ferrea Martius fruit extracts $(25-100 \mu \mathrm{g} / \mathrm{ml})$. C. ferrea (syn. Libidibia ferrea) Mart. is a leguminous plant found in the north and northeastern semiarid region of Brazil and is widely used in folk medicine. Tannins are thought to be the major compounds of its fruits extracts, which also contain alkaloids, anthraquinones, sugars, depsides, depsidones, flavonoids, saponins, sesquiterpene lactones, and triterpenes. Vaccinium (Ericaceae) is a cosmopolitan genus that contains on the order of 450 species. Vaccinium macrocarpon is a native North American fruit. V. macrocarpon is the source of cranberries. The cranberry is a fruit rich in polyphenols including proanthocyanidins, anthocyanins, and flavonols (myricetin, quercetin, kaempferol; Duarte et al., 2006). In addition to its significant antioxidant and antitumor effects, cranberry seems to have high antimicrobial efficacy against several Gram-positive and Gram-negative bacteria and fungi known to be involved in recurrent urinary tract infections (Bonifait and Grenier, 2010). Surprisingly, the cranberry is the fruit with the most distinct antiadhesive properties, a fact which highlights its unique ability to strongly inhibit biofilm formation (Yoo et al., 2011). This can be related to various mechanisms such as the decrease of bacterial membrane hydrophobicity (Yamanaka et al., 2004), reduced activity of the enzymes fructosyltransferase and glycosyltransferase (Steinberg et al., 2004) and decreased $\mathrm{pH}$ values (Duarte et al., 2006). With regard to oral microorganisms, cranberry was found to be highly effective against oral biofilm members of the genus Streptococcus and $P$. gingivalis in previous studies (Yamanaka et al., 2007; Yamanaka-Okada et al., 2008). Yamanaka et al. proved that cranberry extract in concentrations up to $500 \mu \mathrm{g} / \mathrm{ml}$ prevented synergistic biofilm formation by $P$. gingivalis and $F$. nucleatum after $24 \mathrm{~h}$ of incubation (Yamanaka et al., 2007).

Finally, the favorable antibiofilm properties of Chinese galls (Galla Chinensis) were demonstrated by Xie et al. (2008) on in vitro formed biofilms (Streptococcus sanguis, S. mutans, Actinomyces naeslundii, L. rhamnosus). Chinese gall is a common traditional Chinese medicine. It is produced through special aphids [Melaphis chinensis (Bell) Baker] parasitized on the leaves or stems of Rhus chinensis, R. potaninii, or R. punjabensis (Anacardiaceae). Chinese gall has high medicinal value and wide industrial application because of its high levels of gallotannins and various volatile compounds or essential oils. The gallotannins from Chinese galls are quite complex mixtures mostly with degrees of polymerization of 4-11 galloyl units. Biofilm treatment $(1 \mathrm{~min})$ with $4 \mathrm{mg} / \mathrm{ml}$ Galla chinensis extracts (GCE) over 5 days induced increased planktonic phase $\mathrm{pH}$ levels and decreased colony forming unit (CFU) values of biofilm microorganisms.

\section{Herbal Interventions on Ex vivo Formed Multispecies Oral Biofilms}

Table 3 summarizes the herbal treatments on ex vivo formed multispecies oral biofilms. A total of four studies described the effects of five different natural extracts on multispecies oral biofilms generated ex vivo by unstimulated human saliva (Alviano et al., 2008; Antonio et al., 2011, 2012; Meckelburg 
et al., 2014). Alviano et al. screened four Brazilian plant extracts from Cocos nucifera, Ziziphus joazeiro, Caesalpinia pyramidalis, and Aristolochia cymbifera, that are used in folk medicine in the northeast of Brazil to treat oral diseases, against oral biofilms from unstimulated human whole mixed saliva (Alviano et al., 2008). After applying $16 \mathrm{mg} / \mathrm{ml}$ of each extract onto the biofilms for $30 \mathrm{~min}, A$. cymbifera, C. pyramidalis and C. nucifera reduced the viable count of adherent microorganisms by $94.2,72.8$, and $64.1 \%$ after $48 \mathrm{~h}$ of incubation, respectively. The latter two extracts also interfered with the activity of the free radical 1,1-diphenyl-2-picryl-hydrazylhydrate (DPPH). In addition, three further studies by two groups highlighted the antibiofilm activity of C. canephora against oral biofilms originating in saliva (Antonio et al., 2011, 2012; Meckelburg et al., 2014). The roasted beans of Coffea arabica and C. canephora are used for the production of coffee (Nuhu, 2014). Among its active compounds, the alkaloid caffeine (Ferrazzano et al., 2009), chlorogenic acid (Lou et al., 2011), the pyridine alkaloid trigonelline (Antonio et al., 2011), and several diterpenes (bietane, cembrane, guanacastepene A, cafestol) (Bisio et al., 2014) are responsible for the significant antiadhesive behavior of coffee. Coffee was shown to be effective against Grampositive and Gram-negative microorganisms in an earlier study (Daglia et al., 1998). Within the oral cavity in particular, coffee exhibited antiadhesive activity against $S$. mutans and other oral species of the genus Streptococcus (Daglia et al., 2002; Ferrazzano et al., 2009). This could be explained by the ability of caffeine to inhibit quorum sensing, a crucial communication pathway among biofilm microorganisms (Norizan et al., 2013).

The first report by Antonio et al. revealed stable $\mathrm{pH}$ levels and a 4-log decrease in CFU of $S$. mutans after 1-min incubation of $50 \mu \mathrm{g} / \mathrm{ml}$ aqueous coffee extract from C. canephora with oral biofilms originating from unstimulated human saliva over 7 days (Antonio et al., 2011). Interestingly, the results of the second report by the same group were confirmatory (Antonio et al., 2012). In particular, upon treatment for $30 \mathrm{~min}, 20 \mathrm{mg} / \mathrm{ml}$ and sweetened aqueous coffee extracts from $C$. canephora caused a decrease in total bacterial count of $15 \%$ in biofilm derived from saliva (Antonio et al., 2012). Similarly, Meckelburg et al. incubated ex vivo formed oral biofilms with $50 \mu \mathrm{g} / \mathrm{ml}$ aqueous coffee extract from C. canephora for 1 min over 7 days (Meckelburg et al., 2014). In this study, the calcium concentration of the treated biofilms was found to increase, probably due to bacterial lysis.

\section{Herbal Interventions on In situ Formed Multispecies Oral Biofilms}

Table 4 summarizes the herbal treatments on in situ formed multispecies oral biofilms. A total of five studies described the effects of 12 different natural extracts on multispecies oral biofilms obtained in situ by supragingival dental plaque. $P$. cattleianum commonly known as strawberry guava, Chinese guava, cattley guava, Jeju guava, cherry guava, purple guava, waiawi, guayaba, or araçá is an exotic tropical plant belonging to the Myrtaceae family and native to the Atlantic coast of Brazil. Its leaves are rich in vitamin $\mathrm{C}$ and phenolic compounds, including epicatechin and gallic acid as the main components.
They also contain flavonoids, saponins, cardiac glycosides, anthraquinones, and tannins. More specifically, Brighenti et al. treated in situ oral biofilms with $167 \mathrm{mg} / \mathrm{ml} \mathrm{P.} \mathrm{cattleianum} \mathrm{leaf}$ extract for $1 \mathrm{~min}$ at 12 -h intervals over a period of 14 days and reported significantly reduced post-treatment amounts of extracellular polysaccharides and biofilm growth, while $\mathrm{pH}$ levels remained stable (Brighenti et al., 2012). Hannig et al. conducted two studies on the antibiofilm effects of various polyphenolic beverages (Hannig et al., 2008, 2009). In their first study, this group tested cistus tea $(20 \mathrm{mg} / \mathrm{ml})$ against in situ formed initial oral biofilms. Cistus tea is prepared from Cistus incanus, a Mediterranean species rich in polymeric polyphenols. A 10-min treatment was followed by further biofilm incubation in the oral cavity for 20, 40, or 109 min (Hannig et al., 2008). In addition to a decrease in peroxidase activity after $40 \mathrm{~min}$, cistus tea reduced the CFU values of the adherent bacteria, whereas glucosyltransferase-, amylase-, and lysozyme activities were not influenced. In the subsequent study from the same group, a variety of polyphenolic beverages (red wine, purple grape juice, cistus tea, black tea, green tea) were screened (Hannig et al., 2009). In brief, $10 \mathrm{mg} / \mathrm{ml}$ of each of the aforementioned beverages were applied for $10 \mathrm{~min}$ onto in situ formed initial oral biofilms and the splint systems were further kept in the oral cavity for either 19 or $109 \mathrm{~min}$. As a result, the total amount of adherent bacteria decreased significantly up to $66 \%$, with cistus tea, red wine, and grape juice showing the highest bactericidal activity. The dried leaves of the plant Camellia sinensis produce four well-known varieties of tea, namely black, green, Oolong, and white tea. Polyphenols, especially the flavonoid catechin (30-40\% of dry weight), and fluorides are the most active ingredients in tea (Goenka et al., 2013). Tea contains distinct antioxidant properties due to its ability to restrict free radical generation (Reygaert, 2014). Furthermore, tea inhibits the release of antiinflammatory cytokines such as interleukins (IL-6, IL-8, IL-10, IL-12), as well as the receptor activator of nuclear factor kappa-B ligand (RANKL), and acts as an anticancer agent by stimulating apoptotic processes in cancer cells (Chen et al., 2011). In terms of oral health, tea has significant antimicrobial effects. The latter can be attributed to the lysis of the bacterial cell membrane which leads to a reduction in the ability of bacteria to attach to host substrata and form persistent biofilms (Sharma et al., 2012). Other antimicrobial traits involve the interference of tea with the production of fatty acids and enzymes (Reygaert, 2014). For example, tea hinders bacterial energy production by blocking the enzyme ATP synthase (Chinnam et al., 2010). Indeed, numerous studies have revealed a significant bactericidal impact of tea extracts or pure compounds on oral microorganisms such as Streptococcus spp., Aggregatibacter actinomycetemcomitans, Porphyromonas gingivalis, Prevotella intermedia and Enterococcus faecalis (Araghizadeh et al., 2013; Aman et al., 2014).

\section{DISCUSSION}

The present systematic review identified 14 reports on the effects of various medicinal herbs on in vitro, ex vivo, and in situ formed multispecies oral biofilms. The pooled data from 
14 reports revealed the beneficial anti-biofilm behavior of the tested plant extracts (Yamanaka et al., 2007; Alviano et al., 2008; Furiga et al., 2008, 2014; Hannig et al., 2008, 2009; Xie et al., 2008; Sampaio et al., 2009; Antonio et al., 2011, 2012; Badet and Quero, 2011; Brighenti et al., 2012; Meckelburg et al., 2014; Muñoz-Gonzalez et al., 2014). Overall, it can be stated that there is a positive correlation between therapy protocols based on the use of medicinal herbs and the eradication rates of the treated oral biofilms. Independent of the origin of the multispecies oral biofilms (in vitro, ex vivo, or in situ), all herbs succeeded in reducing the total bacterial counts of the adherent microorganisms. Among the tested plant extracts with confirmed biofilm-killing properties, grape-, pinus-, and other oenological extracts (Furiga et al., 2008, 2014; Hannig et al., 2009; MuñozGonzalez et al., 2014), coffee extracts from C. canephora (Antonio et al., 2011, 2012; Meckelburg et al., 2014), as well as polyphenolic beverages such as tea (black tea, green tea, cistus tea; Hannig et al., 2008, 2009) played a major role. Some fruits e.g., cranberry juice concentrate (Yamanaka et al., 2007), C. ferrea Martius fruit extracts (Sampaio et al., 2009), manuka honey (Badet and Quero, 2011) and other tree- or leaf extracts such as Chinese galls (Xie et al., 2008), P. cattleianum leaf extract (Brighenti et al., 2012), and Brazilian tree extracts (Alviano et al., 2008) also showed pronounced antibiofilm activity.

\section{REVIEW LIMITATIONS}

For a number of reasons the outcomes from the present review should be interpreted avoiding generalized assumptions. Due to methodological heterogeneity among the studies presented, recommendation of specific treatment protocols with the medicinal herbs studied is not possible. In particular, despite the fact that they are well-described in most reports, the extraction methods applied to the tested herbs, e.g., boiling, differed from one another. Another crucial methodological parameter for the antimicrobial behavior of the herbs studied is the solvent used for the extraction. Here, methanol was utilized as a solvent for the extraction in most reports, whereas aqueous extracts were utilized in some other cases (Alviano et al., 2008; Antonio et al., 2011, 2012; Brighenti et al., 2012; Meckelburg et al., 2014). Furthermore, the quantities used to test the extracts ranged between $50 \mu \mathrm{g} / \mathrm{ml}$ and $300 \mathrm{mg} / \mathrm{ml}$, a fact which can directly affect their anti-biofilm effectiveness. The latter can also be influenced by the duration of treatment, which varied from $1 \mathrm{~min}$ (Furiga et al., 2008, 2014; Hannig et al., 2008, 2009; Xie et al., 2008; Sampaio et al., 2009; Antonio et al., 2011; Brighenti et al., 2012; Meckelburg et al., 2014) to $64 \mathrm{~h}$ (Badet and Quero, 2011). Obviously, a therapy with an extended treatment time can lead to an overestimation of the positive antimicrobial effects of the plant extract. In addition, the origin of the multispecies oral biofilms studied could be added to the limitations of this review. The different in vitro, ex vivo and in situ formed multispecies oral biofilms were characterized by a variety of bacterial compositions., which could therefore lead to variation in their response mechanisms toward the applied herbal remedies. The biofilm incubation time prior to and after the herbal treatment, as well as the incubation conditions used (aerobic/anaerobic), also presented discrepancies among the studies presented. Finally, language bias could be a further restriction of this study since only reports written in English were included and only English and German journals were initially taken into consideration.

\section{Impact of Herbs on Oral Biofilms}

In spite of the heterogeneous methodological aspects of the presented studies mentioned above, the general tendency of various natural plant extracts to possess pronounced antiadhesive and anti-biofilm traits cannot be disputed. Indeed, this antimicrobial behavior was confirmed in the reports analyzed in this review. Since the answer to the general question: "Can herbal intervention eradicate multispecies oral biofilms?" is affirmative, the next question arises: "Exactly which herbal interventions can eradicate multispecies oral biofilms?"

Based on the pooled data in the present review, the extracts from $V$. vinifera seem to be the most promising on the candidate herb list. Interestingly, more than $80 \%$ of the polyphenol-rich wine grapes end up in the winemaking process (Thimothe et al., 2007). Thus, the following materials with anti-biofilm properties can be included in this group: red GME, RWE, grape seed extract and red wine. Previous in vitro studies also showed a high bactericidal activity for grape extracts against planktonic $S$. mutans, probably due to their interference with glycosyltransferase (GTF) activity, a fact that indirectly inhibits dental plaque accumulation (Thimothe et al., 2007). This assumption was confirmed for multispecies oral biofilms by Furiga et al. (2014), as they showed decreased GTF activity (43.9\%) and insoluble glucan synthesis (65.7\%) in the presence of grape seed extract. Proanthocyanidins and red pigments are considered to be anti-adhesive components able to modify host and bacterial receptors such as bacterial adhesins (Signoretto et al., 2012).

Furthermore, in the present review coffee was found to be another effective biofilm "killer." This can be attributed to its enhanced anti-adhesive and anti-biofilm properties as also demonstrated in earlier in vitro studies on planktonic bacteria. In particular, low molecular mass substances [chlorogenic acid (Lou et al., 2011), trigonelline (Antonio et al., 2011)] and high molecular mass substances, e.g., melanoidin (Papetti et al., 2007), inhibited the adhesion of $S$. mutans to hydroxyapatite-containing tooth surfaces, as mentioned in the introduction. These components are not only capable of hindering the initiation of the biofilm formation process, but they can also interfere with substantial biofilm communication mechanisms such as quorum sensing (Norizan et al., 2013). However, when combined with additives like sugar, coffee tends to show cariogenic properties within the oral cavity (Anila Namboodiripad and Kori, 2009). Nevertheless, in one of the studies presented (Antonio et al., 2012) sweetened aqueous coffee extracts from C. canephora with sucrose concentrations from 5 up to $20 \%$ significantly reduced the total bacterial count of biofilm microorganisms.

Tea is currently one of the most popular healthy beverages worldwide. In this review, its beneficial anti-adhesive and antibiofilm contribution against multispecies oral biofilms was highlighted. As mentioned in the introduction, tea has the 
ability to either directly affect biofilm viability by destroying the bacterial membrane, or to indirectly affect it by interfering with microbial adhesion to various oral surfaces (Reygaert, 2014). Nevertheless, the consumption of tea with sweeteners should be avoided since the positive impact of tea is then minimized (Morabia and Costanza, 2010). Moreover, the biofilm inhibiting use of fruits, especially cranberries and C. ferrea Martius, manuka honey and other tree- or leaf extracts is promising. Several in vitro reports have also underlined their favorable impacts on planktonic bacteria (Babu et al., 2012; Eick et al., 2014).

A general response to the question "How do herbal interventions eradicate multispecies oral biofilms?" should include mention of the small-molecule antimicrobial agents (molecular weight, MW < 500) named phytoalexins. These active natural antibiotics consist of heterogeneous components like polyphenols, terpenoids, flavonoids, alkaloids, and glycosteroids. These constitute an herbal "defense reservoir" against pathogenic microorganisms (Hemaiswarya et al., 2008). Interestingly, phytoalexins are capable of acting synergistically in order to eradicate different pathogens. Other plant defense mechanisms against microbial invaders involve the expression of avirulence (Avr) genes, which results in the release of resistance (R) proteins and the local secretion of sugar polymers e.g., callose (Maor and Shirasu, 2005).

Table 5 summarizes the most representative active compounds of the extracts studied in the 14 reviewed reports with antimicrobial activity against oral multispecies biofilms.

\section{FUTURE PROSPECTS}

The following plants have been screened for their antimicrobial activity against planktonic and monospecies biofilm microorganisms and could be also be tested against multispecies biofilm microorganisms in the future.

\section{Theobroma cacao (Cacao)}

The widely used cacao comes from the plant Theobroma cacao. Depending on the degree of cocoa fermentation, the most important flavonoid compounds of cocoa are catechin and epigallocathechin (6-8\% of dry weight) (Ferrazzano et al., 2009). In addition to its anti-inflammatory, antioxidant, and anticarcinogenic benefits, cacao possesses significant anticariogenic properties (van Loveren et al., 2012). A possible mechanism for its anticariogenic action involves the inhibition of enzymatic activity of dextransucrase, resulting in reduced production of sucrose-originated extracellular polysaccharides (Ferrazzano et al., 2009). This leads to decreased biofilm formation as shown for Streptococcus mutans and Streptococcus sanguis in a previous study (Percival et al., 2006).

\section{Punica granatum (Pomegranate)}

The fruit pomegranate is obtained from the plant Punica granatum. Pomegranate demonstrates an astounding antioxidant activity, which can be ascribed to several of its compounds, namely tannins (punicalagins, punicalins), anthocyanins, gallic acid, and ellagic acid (Kote et al., 2011). Pomegranate interferes with biofilm formation by inhibiting antibiotic-resistant bacterial
TABLE 5 | Representative compounds of extracts with antimicrobial activity against oral multispecies biofilms.

Name of
medicinal
herb

Grape seed Catechin
extract
(GSE)

Red wine Benzoic acids (e.g., protocatechuic acid)<smiles>O=C(O)c1ccc(O)c(O)c1</smiles>

Phenols (e.g., phloroglucinol)<smiles>Oc1cc(O)cc(O)c1</smiles>

Cinnamic acids (e.g., p-coumaric acid)<smiles>O=C(O)/C=C/c1ccc(O)cc1</smiles>

Stilbene (e.g., resveratrol)<smiles>Oc1ccc(/C=C/c2cc(O)cc(O)c2)cc1</smiles>

Procyanidin (e.g., procyanidin B1)

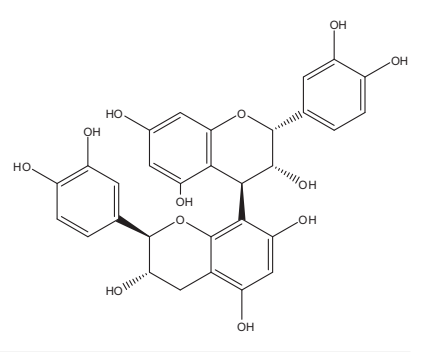


TABLE 5 | Continued

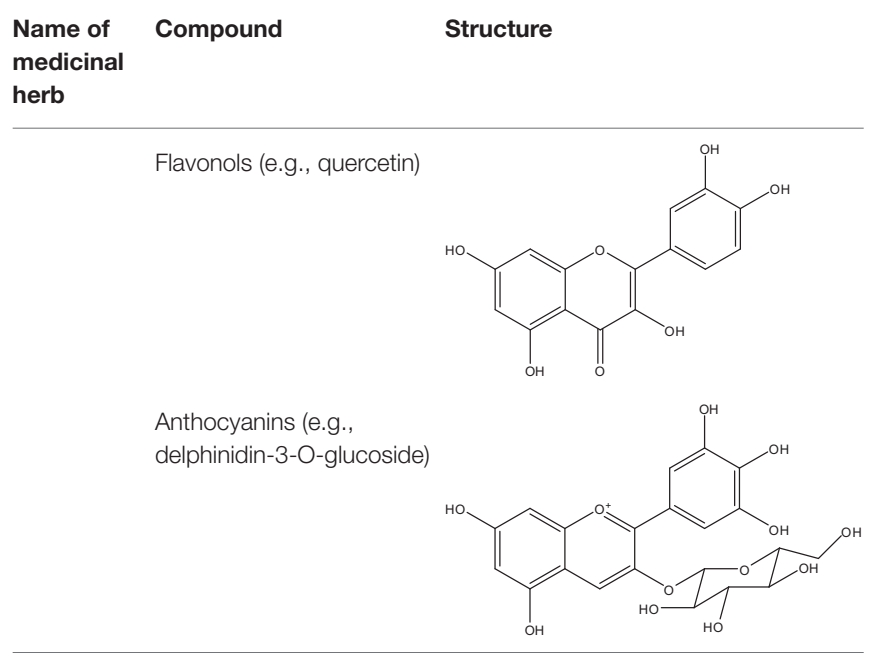

TABLE 5 | Continued

Name of Compound Structure
medicinal
herb

Anthocyanins (e.g., cyanidin-3-O-glucoside)<smiles></smiles>

Grape seed Benzoic acids (e.g., gallic extract acid)<smiles>O=C(O)c1cc(O)c(Br)c(Cl)c1</smiles>

Procyanidin (e.g., procyanidin B3)

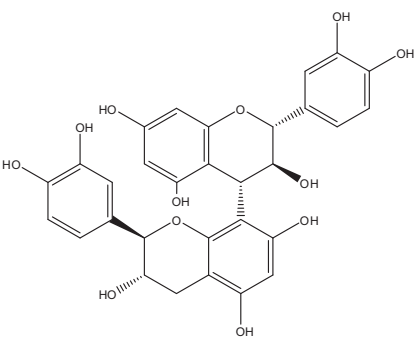

Procyanidin (e.g., procyanidin B2)<smiles>O=C(/C=C/c1ccc(O)cc1)O[C@H](C(=O)O)[C@@H](O)C(=O)O</smiles>

Stilbene (e.g., resveratrol)<smiles>Oc1ccc(/C=C/c2cc(O)cc(O)c2)cc1</smiles><smiles>Oc1cc(O)c2c(c1)O[C@H](c1ccc(O)c(O)c1)[C@H](O)[C@H]2c1c(O)cc(O)c2c1O[C@H](c1ccc(O)c(O)c1)[C@H](O)C2</smiles>

Flavonols (e.g., myricetin)<smiles>O=c1c(O)c(-c2cc(O)c(O)c(O)c2)oc2cc(O)cc(O)c12</smiles>

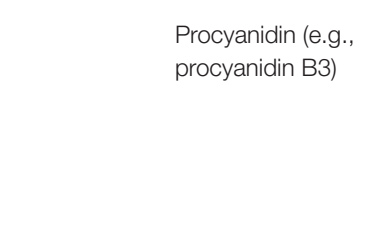

extact

(GCE)

Aqueous Chlorogenic acid
coffee
extract from
Coffea
canephora

Neochlorogenic acid<smiles>O=C(/C=C/c1ccc(O)c(O)c1)O[C@@H]1CC(O)(O)C[C@H](O)[C@H]1O</smiles>

3-feruloylquinic acid<smiles>COc1cc(/C=C/C(=O)O[C@@H]2CC(O)(O)C[C@H](O)[C@H]2O)ccc1O</smiles>

Cryptochlorogenic acid 
TABLE 5 | Continued

Name of Compound $\quad$ Structure
medicinal
herb

5-feruloylquinic acid<smiles>COc1cc(/C=C/C(=O)O[C@@H]2CC(O)(O)C[C@@H](O)[C@H]2O)ccc1O</smiles>

4-feruloylquinic acid<smiles>COc1cc(/C=C/C(=O)O[C@H]2[C@@H](O)CC(O)(O)C[C@H]2O)ccc1O</smiles>

3,4-dicaffeoylquinic acid<smiles>O=C(/C=C/c1ccc(O)c(O)c1)O[C@H]1[C@@H](O)C[C@@](O)(C(=O)O)C[C@H]1OC(=O)/C=C/c1ccc(O)c(O)c1</smiles>

3,5-dicaffeoylquinic acid

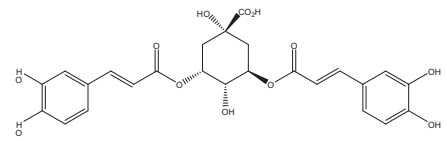

4,5-dicaffeoylquinic acid<smiles>C[C@@H]1CC(O)(O)C[C@@H](OC(=O)/C=C/c2ccc(O)c(O)c2)[C@@H]1OC(=O)/C=C/c1ccc(O)c(O)c1</smiles>

Caffeic acid<smiles>O=C(O)/C=C/c1ccc(O)c(O)c1</smiles>

Caffeine<smiles>Cn1c(=O)c2c(ncn2C)n(C)c1=O</smiles>

Trigonelline<smiles></smiles>

TABLE 5 | Continued

Name of Compound Structure
medicinal
herb

Cistus tea Catechin

Myricetin-galactoside<smiles>O=c1c(O[C@@H]2O[C@H](CO)[C@@H](O)[C@H](O)[C@H]2O)c(-c2cc(O)c(O)c(O)c2)oc2cc(O)cc(O)c12</smiles>

Myricetin-rhamnoside<smiles>C[C@@H]1O[C@H](Oc2c(-c3cc(O)c(O)c(O)c3)oc3cc(O)cc(O)c3c2=O)[C@H](O)[C@@H](O)[C@H]1O</smiles>

Quercetin-glucoside

strains and quorum sensing among biofilm microorganisms. Pomegranate was effective at eradicating oral microorganisms e.g., S. salivarius, S. sanguis, Streptococcus mitis, P. gingivalis, $A$. actinomycetemcomitans, and $P$. intermedia in previous studies (Menezes et al., 2006; de Oliveira et al., 2013).

\section{Allium sativum (Garlic)}

Garlic (Allium sativum) is well-known for its antiviral and antimicrobial activities (Shetty et al., 2013). These activities are associated with the alliinase-derived allicin, a bioactive compound found in garlic (Ankri and Mirelman, 1999). Interestingly microorganisms were shown to be up to 1000 times more prone to antibiotic resistance than to allicin resistance (Cutler and Wilson, 2004). Apart from being effective against MRSA, garlic has also demonstrated antibacterial action in 
the dental field, namely against several planktonic Grampositive and Gram-negative bacteria (A. naeslundii, E. faecalis, $P$. intermedia, $P$. gingivalis, $F$. nucleatum), as well as against S. mutans biofilms (Bakri and Douglas, 2005; Lee et al., 2011).

\section{Curcuma xanthorrhiza (Javanese Ginger)}

Javanese ginger (Curcuma xanthorrhiza) contains xanthorrhizol, which shows antiinflammatory, anticancer, and antibacterial activity (Kim et al., 2008). The latter is mainly attributed to the lysis of the bacterial cell membrane by xanthorrhizol (Rukayadi and Hwang, 2006). Javanese ginger was shown to be effective not only against planktonic oral microorganisms, but in earlier studies was also shown to be effective against S. mutans biofilms (Rukayadi and Hwang, 2006; Kim et al., 2008).

\section{Pistacia lentiscus (Mastic Gum)}

Mastic gum (Pistacia lentiscus) is a resinous exudate with a wide-spectrum of antibacterial and antifungal activity (Sakagami et al., 2009). Mastic gum consists of several volatile compounds, namely $\alpha$-pinene, $\beta$-caryophyllene, $\beta$ myrcene, $\beta$-pinene, and limonene (Paraschos et al., 2012). Triterpenic acids in particular are considered to be the most active ingredients of mastic gum, with high bactericidal effects, especially against Helicobacter pylori (Paraschos et al., 2007). Recently, the effectiveness of mastic gum against anaerobic oral pathogens such as $P$. gingivalis, $P$. intermedia, and F. nucleatum was reported (Karygianni et al., 2014a).

\section{REFERENCES}

Achtman, M., and Wagner, M. (2008). Microbial diversity and the genetic nature of microbial species. Nat. Rev. Microbiol. 6, 431-440. doi: 10.1038/nrmicro1872 Afolabi, O. C., Ogunsola, F. T., and Coker, A. O. (2008). Susceptibility of cariogenic Streptococcus mutans to extracts of Garcinia kola, Hibiscus sabdariffa, and Solanum americanum. West Afr. J. Med. 27, 230-233.

Al-Ahmad, A., Ameen, H., Pelz, K., Karygianni, L., Wittmer, A., Anderson, A. C., et al. (2014). Antibiotic resistance and capacity for biofilm formation of different bacteria isolated from endodontic infections associated with rootfilled teeth. J Endod. 40, 223-230. doi: 10.1016/j.joen.2013.07.023

Al-Ahmad, A., Wunder, A., Auschill, T. M., Follo, M., Braun, G., Hellwig, E., et al. (2007). The in vivo dynamics of Streptococcus spp., Actinomyces naeslundii, Fusobacterium nucleatum and Veillonella spp. in dental plaque biofilm as analysed by five-colour multiplex fluorescence in situ hybridization. J. Med. Microbiol. 56, 681-687. doi: 10.1099/jmm.0.47094-0

Alviano, W. S., Alviano, D. S., Diniz, C. G., Antoniolli, A. R., Alviano, C. S., Farias, L. M., et al. (2008). In vitro antioxidant potential of medicinal plant extracts and their activities against oral bacteria based on Brazilian folk medicine. Arch. Oral Biol. 53, 545-552. doi: 10.1016/j.archoralbio.2007.12.001

Aman, S., Naim, A., Siddiqi, R., and Naz, S. (2014). Antimicrobial polyphenols from small tropical fruits, tea and spice oilseeds. Food Sci. Technol. Int. 20, 241-251. doi: 10.1177/1082013213482476

Anila Namboodiripad, P., and Kori, S. (2009). Can coffee prevent caries? J. Conserv. Dent. 12, 17-21. doi: 10.4103/0972-0707.53336

Ankri, S., and Mirelman, D. (1999). Antimicrobial properties of allicin from garlic. Microbes Infect. 1, 125-129. doi: 10.1016/S1286-4579(99)80003-3

\section{CONCLUSIONS}

In conclusion, the outcomes of this review have disclosed the anti-adhesive and anti-biofilm effectiveness of selected natural plant extracts against multispecies oral biofilms. Overall, extracts from V. vinifera, Pinus spp. C. canephora, C. sinensis, $V$. macrocarpon, G. chinensis, C. ferrea Martius, P. cattleianum, representative Brazilian plants and manuka honey have proven effective against the tested in vitro, ex vivo, and in situ formed multispecies oral biofilms. The above-mentioned beneficial properties lead to increased interest in the introduction of natural phytochemicals into the therapeutic repertoire of dentistry. Side-effect free medicinal herbs could in this way supplement or even substitute for conventional antiinfectious agents in the battle against periodontitis and other biofilmrelated diseases.

\section{AUTHOR CONTRIBUTIONS}

LK, AS conceived the idea for this review; LK, AA conducted search of the relevant databases and participated in the study design; AA-A and ACA organized the data and evaluated their quality; EH, LK, AA, and AS were involved in the data analysis, wrote, and critically reviewed the manuscript. All authors read and approved the final manuscript.

\section{ACKNOWLEDGMENTS}

This study was supported in part by the European Commission (FP7-280741-LONGLIFE Collaborative project) and the German Research Foundation (DFG, AL 1179/2-1).

Antonio, A. G., Iorio, N. L., Farah, A., Netto dos Santos, K. R., and Maia, L. C. (2012). Effect of Coffea canephora aqueous extract on microbial counts in ex vivo oral biofilms: a case study. Planta Med. 78, 755-760. doi: 10.1055/s-00311298435

Antonio, A. G., Iorio, N. L., Pierro, V. S., Candreva, M. S., Farah, A., dos Santos, K. R., et al. (2011). Inhibitory properties of Coffea canephora extract against oral bacteria and its effect on demineralisation of deciduous teeth. Arch. Oral Biol. 56, 556-564. doi: 10.1016/j.archoralbio.2010.12.001

Araghizadeh, A., Kohanteb, J., and Fani, M. M. (2013). Inhibitory activity of green tea (Camellia sinensis) extract on some clinically isolated cariogenic and periodontopathic bacteria. Med. Princ. Pract. 22, 368-372. doi: $10.1159 / 000348299$

Babu, J., Blair, C., Jacob, S., and Itzhak, O. (2012). Inhibition of Streptococcus gordonii metabolic activity in biofilm by cranberry juice high-molecular-weight component. J. Biomed. Biotechnol. 2012:590384. doi: 10.1155/2012/590384

Badet, C., and Quero, F. (2011). The in vitro effect of manuka honeys on growth and adherence of oral bacteria. Anaerobe 17, 19-22. doi: 10.1016/j.anaerobe.2010.12.007

Bagchi, D., Bagchi, M., Stohs, S. J., Das, D. K., Ray, S. D., Kuszynski, C. A., et al. (2000). Free radicals and grape seed proanthocyanidin extract: importance in human health and disease prevention. Toxicology 148, 187-197. doi: 10.1016/S0300-483X(00)00210-9

Bairy, I., Reeja, S., Siddharth, Rao, P. S., Bhat, M., and Shivananda, P.G. (2002). Evaluation of antibacterial activity of Mangifera indica on anaerobic dental microglora based on in vivo studies. Indian J. Pathol. Microbiol. 45, 307-310.

Bakri, I. M., and Douglas, C. W. (2005). Inhibitory effect of garlic extract on oral bacteria. Arch. Oral Biol. 50, 645-651. doi: 10.1016/j.archoralbio.2004.12.002 
Bardají, D. K., Reis, E. B., Medeiros, T. C., Lucarini, R., Crotti, A. E., and Martins, C. H. (2015). Antibacterial activity of commercially available plantderived essential oils against oral pathogenic bacteria. Nat. Prod. Res. doi: 10.1080/14786419.2015.1043630. [Epub ahead of print].

Bisio, A., Schito, A. M., Ebrahimi, S. N., Hamburger, M., Mele, G., Piatti, G., et al. (2014). Antibacterial compounds from Salvia adenophora Fernald (Lamiaceae). Phytochemistry 110, 120-132. doi: 10.1016/j.phytochem.2014.10.033

Bonifait, L., and Grenier, D. (2010). Cranberry polyphenols: potential benefits for dental caries and periodontal disease. J. Can. Dent. Assoc. 76:a130.

Brighenti, F. L., Gaetti-Jardim, E. Jr., Danelon, M., Evangelista, G. V., and Delbem, A. C. (2012). Effect of Psidium cattleianum leaf extract on enamel demineralisation and dental biofilm composition in situ. Arch. Oral Biol. 57, 1034-1040. doi: 10.1016/j.archoralbio.2012.02.009

Chen, D., Wan, S. B., Yang, H., Yuan, J., Chan, T. H., and Dou, Q. P. (2011). EGCG, green tea polyphenols and their synthetic analogs and prodrugs for human cancer prevention and treatment. Adv. Clin. Chem. 53, 155-177. doi: 10.1016/B978-0-12-385855-9.00007-2

Chinnam, N., Dadi, P. K., Sabri, S. A., Ahmad, M., Kabir, M. A., and Ahmad, Z. (2010). Dietary bioflavonoids inhibit Escherichia coli ATP synthase in a differential manner. Int. J. Biol. Macromol. 46, 478-486. doi: 10.1016/j.ijbiomac.2010.03.009

Cutler, R. R., and Wilson, P. (2004). Antibacterial activity of a new, stable, aqueous extract of allicin against methicillin-resistant Staphylococcus aureus. Br. J. Biomed. Sci. 61, 71-74.

Daglia, M., Papetti, A., Dacarro, C., and Gazzani, G. (1998). Isolation of an antibacterial component from roasted coffee. J. Pharm. Biomed. Anal. 18, 219-225. doi: 10.1016/S0731-7085(98)00177-0

Daglia, M., Tarsi, R., Papetti, A., Grisoli, P., Dacarro, C., Pruzzo, C., et al. (2002). Antiadhesive effect of green and roasted coffee on Streptococcus mutans' adhesive properties on saliva-coated hydroxyapatite beads. J. Agric. Food Chem. 50, 1225-1229. doi: 10.1021/jf010958t

de Oliveira, J. R., de Castro, V. C., das Graças Figueiredo Vilela, P., Camargo, S. E., Carvalho, C. A., Jorge, A. O., et al. (2013). Cytotoxicity of Brazilian plant extracts against oral microorganisms of interest to dentistry. BMC Complement. Altern. Med. 13:208. doi: 10.1186/1472-6882-13-208

Duarte, S., Gregoire, S., Singh, A. P., Vorsa, N., Schaich, K., Bowen, W. H., et al. (2006). Inhibitory effects of cranberry polyphenols on formation and acidogenicity of Streptococcus mutans biofilms. FEMS Microbiol. Lett. 257, 50-56. doi: 10.1111/j.1574-6968.2006.00147.x

Dziedzic, A., Kubina, R., Wojtyczka, R. D., Kabala-Dzik, A., Tanasiewicz, M., and Morawiec, T. (2013). The antibacterial effect of ethanol extract of polish propolis on mutans streptococci and lactobacilli isolated from saliva. Evid. Based Complement. Alternat. Med. 2013:681891. doi: 10.1155/2013/681891

Eick, S., Schäfer, G., Kwiecinski, J., Atrott, J., Henle, T., and Pfister, W. (2014). Honey - a potential agent against Porphyromonas gingivalis: an in vitro study. BMC Oral Health 14:24. doi: 10.1186/1472-6831-14-24

Fani, M., and Kohanteb, J. (2012). Inhibitory activity of Aloe vera gel on some clinically isolated cariogenic and periodontopathic bacteria. J. Oral Sci. 54, 15-21. doi: 10.2334/josnusd.54.15

Ferrazzano, G. F., Amato, I., Ingenito, A., De Natale, A., and Pollio, A. (2009). Anticariogenic effects of polyphenols from plant stimulant beverages (cocoa, coffee, tea). Fitoterapia 80, 255-262. doi: 10.1016/j.fitote.2009.04.006

Furiga, A., Lonvaud-Funel, A., Dorignac, G., and Badet, C. (2008). In vitro anti-bacterial and anti-adherence effects of natural polyphenolic compounds on oral bacteria. J. Appl. Microbiol. 105, 1470-1476. doi: 10.1111/j.13652672.2008.03882.x

Furiga, A., Roques, C., and Badet, C. (2014). Preventive effects of an original combination of grape seed polyphenols with amine fluoride on dental biofilm formation and oxidative damage by oral bacteria. J. Appl. Microbiol. 116, 761-771. doi: 10.1111/jam.12395

Furletti, V. F., Teixeira, I. P., Obando-Pereda, G., Mardegan, R. C., Sartoratto, A., Figueira, G. M., et al. (2011). Action of Coriandrum sativum L. Essential oil upon oral Candida albicans biofilm formation. Evid. Based Complement. Alternat. Med. 2011:985832. doi: 10.1155/2011/985832

Goenka, P., Sarawgi, A., Karun, V., Nigam, A. G., Dutta, S., and Marwah, N. (2013). Camellia sinensis (Tea): implications and role in preventing dental decay. Pharmacogn. Rev. 7, 152-156. doi: 10.4103/0973-7847.120515
Groppo, F. C., Bergamaschi Cde, C., Cogo, K., Franz-Montan, M., Motta, R. H., and de Andrade, E. D. (2008). Use of phytotherapy in dentistry. Phytother. Res. 22, 993-998. doi: 10.1002/ptr.2471

Gupta, D., and Gupta, R. K. (2015). Investigation of antibacterial efficacy of Acacia nilotica against salivary mutans streptococci: a randomized control trial. Gen. Dent. 63, 23-27.

Hamilton-Miller, J. M. (2001). Anti-cariogenic properties of tea (Camellia sinensis). J. Med. Microbiol. 50, 299-302. doi: 10.1099/0022-1317-50-4-299

Hannig, C., Sorg, J., Spitzmüller, B., Hannig, M., and Al-Ahmad, A. (2009). Polyphenolic beverages reduce initial bacterial adherence to enamel in situ. J. Dent. 37, 560-566. doi: 10.1016/j.jdent.2009.03.017

Hannig, C., Spitzmüller, B., Al-Ahmad, A., and Hannig, M. (2008). Effects of Cistus-tea on bacterial colonization and enzyme activities of the in situ pellicle. J. Dent. 36, 540-545. doi: 10.1016/j.jdent.2008.04.002

Hemaiswarya, S., Kruthiventi, A. K., and Doble, M. (2008). Synergism between natural products and antibiotics against infectious diseases. Phytomedicine 15, 639-652. doi: 10.1016/j.phymed.2008.06.008

Howell, A. B., and D'Souza, D. H. (2013). The pomegranate: effects on bacteria and viruses that influence human health. Evid. Based Complement. Alternat. Med. 2013:606212. doi: 10.1155/2013/606212

Islam, B., Khan, S. N., Haque, I., Alam, M., Mushfiq, M., and Khan, A. U. (2008) Novel anti-adherence activity of mulberry leaves: inhibition of Streptococcus mutans biofilm by 1-deoxynojirimycin isolated from Morus alba. J. Antimicrob. Chemother. 62, 751-757. doi: 10.1093/jac/dkn253

Karygianni, L., Cecere, M., Skaltsounis, A. L., Argyropoulou, A., Hellwig, E., Aligiannis, N., et al. (2014a). High-level antimicrobial efficacy of representative Mediterranean natural plant extracts against oral microorganisms. Biomed. Res. Int. 2014:839019. doi: 10.1155/2014/839019

Karygianni, L., Ruf, S., Follo, M., Hellwig, E., Bucher, M., Anderson, A. C., et al. (2014b). Novel broad-spectrum antimicrobial photoinactivation of in situ oral biofilms using visible light plus water-filtered infrared-A (VIS + wIRA). Appl. Environ. Microbiol. 80, 7324-7336. doi: 10.1128/AEM.02490-14

Kim, J. E., Kim, H. E., Hwang, J. K., Lee, H. J., Kwon, H. K., and Kim, B. I. (2008). Antibacterial characteristics of Curcuma xanthorrhiza extract on Streptococcus mutans biofilm. J. Microbiol. 46, 228-232. doi: 10.1007/s12275-007-0167-7

Kolenbrander, P. E., Palmer, R. J. Jr., Periasamy, S., and Jakubovics, N. S. (2010). Oral multispecies biofilm development and the key role of cell-cell distance. Nat. Rev. Microbiol. 8, 471-480. doi: 10.1038/nrmicro2381

Koo, H., Falsetta, M. L., and Klein, M. I. (2013). The exopolysaccharide matrix: a virulence determinant of cariogenic biofilm. J. Dent. Res. 92, 1065-1073. doi: $10.1177 / 0022034513504218$

Kote, S., Kote, S., and Nagesh, L. (2011). Effect of pomegranate juice on dental plaque microorganisms (streptococci and lactobacilli). Anc. Sci. Life 31, 49-51.

Lee, H. J., Park, H. S., Kim, K. H., Kwon, T. Y., and Hong, S. H. (2011). Effect of garlic on bacterial biofilm formation on orthodontic wire. Angle Orthod. 81, 895-900. doi: 10.2319/121010-713.1

Liberati, A., Altman, D. G., Tetzlaff, J., Mulrow, C., Gøtzsche, P. C., Ioannidis, J. P., et al. (2009). The PRISMA statement for reporting systematic reviews and meta-analyses of studies that evaluate health care interventions: explanation and elaboration. PLoS Med. 6:e1000100. doi: 10.1371/journal.pmed.1000100

Lou, Z., Wang, H., Zhu, S., Ma, C., and Wang, Z. (2011). Antibacterial activity and mechanism of action of chlorogenic acid. J. Food Sci. 76, M398-M403. doi: 10.1111/j.1750-3841.2011.02213.x

Madianos, P. N., Bobetsis, Y. A., and Kinane, D. F. (2005). Generation of inflammatory stimuli: how bacteria set up inflammatory responses in the gingiva. J. Clin. Periodontol. 32(Suppl. 6), 57-71. doi: 10.1111/j.1600051X.2005.00821.x

Maor, R., and Shirasu, K. (2005). The arms race continues: battle strategies between plants and fungal pathogens. Curr. Opin. Microbiol. 8, 399-404. doi: 10.1016/j.mib.2005.06.008

Meckelburg, N., Pinto, K. C., Farah, A., Iorio, N. L., Pierro, V. S., dos Santos, K. R., et al. (2014). Antibacterial effect of coffee: calcium concentration in a culture containing teeth/biofilm exposed to Coffea Canephora aqueous extract. Lett. Appl. Microbiol. 59, 342-347. doi: 10.1111/lam.12281

Menezes, S. M., Cordeiro, L. N., and Viana, G. S. (2006). Punica granatum (pomegranate) extract is active against dental plaque. J. Herb. Pharmacother. 6, 79-92. doi: 10.1080/J157v06n02_07 
Miller, A. B., Cates, R. G., Lawrence, M., Soria, J. A., Espinoza, L. V., Martinez, J. V., et al. (2015). The antibacterial and antifungal activity of essential oils extracted from Guatemalan medicinal plants. Pharm. Biol. 53, 548-554. doi: $10.3109 / 13880209.2014 .932391$

Morabia, A., and Costanza, M. C. (2010). Tea, coffee, and sweet tooth: towards a Japanese paradox. Prev. Med. 50, 157-158. doi: 10.1016/j.ypmed.2010.02.012

Muñoz-González, I., Thurnheer, T., Bartolomé, B., and Moreno-Arribas, M. V. (2014). Red wine and oenological extracts display antimicrobial effects in an oral bacteria biofilm model. J. Agric. Food Chem. 62, 4731-4737. doi: $10.1021 /$ jf501768p

Nagata, H., Inagaki, Y., Yamamoto, Y., Maeda, K., Kataoka, K., Osawa, K., et al. (2006). Inhibitory effects of macrocarpals on the biological activity of Porphyromonas gingivalis and other periodontopathic bacteria. Oral Microbiol. Immunol. 21, 159-163. doi: 10.1111/j.1399-302X.2006.00269.x

Ngo, L. T., Okogun, J. I., and Folk, W. R. (2013). 21st century natural product research and drug development and traditional medicines. Nat. Prod. Rep. 30, 584-592. doi: 10.1039/c3np20120a

Nikitkova, A. E., Haase, E. M., and Scannapieco, F. A. (2013). Taking the starch out of oral biofilm formation: molecular basis and functional significance of salivary alpha-amylase binding to oral streptococci. Appl. Environ. Microbiol. 79, 416-423. doi: 10.1128/AEM.02581-12

Norizan, S. N., Yin, W. F., and Chan, K. G. (2013). Caffeine as a potential quorum sensing inhibitor. Sensors (Basel) 13, 5117-5129. doi: 10.3390/s130405117

Nostro, A., Cannatelli, M. A., Crisafi, G., Musolino, A. D., Procopio, F., and Alonzo, V. (2004). Modifications of hydrophobicity, in vitro adherence and cellular aggregation of Streptococcus mutans by Helichrysum italicum extract. Lett. Appl. Microbiol. 38, 423-427. doi: 10.1111/j.1472-765X.2004.01509.x

Nuhu, A. A. (2014). Bioactive micronutrients in coffee: recent analytical approaches for characterization and quantification. ISRN Nutr 2014:384230. doi: $10.1155 / 2014 / 384230$

Oliveira, S. A., Zambrana, J. R., Iorio, F. B., Pereira, C. A., and Jorge, A. O. (2014). The antimicrobial effects of Citrus limonum and Citrus aurantium essential oils on multi-species biofilms. Braz. Oral Res. 28, 22-27. doi: 10.1590/S180683242013005000024

Paddon, C. J., Westfall, P. J., Pitera, D. J., Benjamin, K., Fisher, K., Mcphee, D., et al. (2013). High-level semi-synthetic production of the potent antimalarial artemisinin. Nature 496, 528-532. doi: 10.1038/nature12051

Papetti, A., Pruzzo, C., Daglia, M., Grisoli, P., Bacciaglia, A., Repetto, B., et al. (2007). Effect of barley coffee on the adhesive properties of oral streptococci. J. Agric. Food Chem. 55, 278-284. doi: 10.1021/jf062090i

Paraschos, S., Magiatis, P., Mitakou, S., Petraki, K., Kalliaropoulos, A., Maragkoudakis, P., et al. (2007). In vitro and in vivo activities of Chios mastic gum extracts and constituents against Helicobacter pylori. Antimicrob. Agents Chemother. 51, 551-559. doi: 10.1128/AAC.00642-06

Paraschos, S., Mitakou, S., and Skaltsounis, A. L. (2012). Chios gum mastic: a review of its biological activities. Curr. Med. Chem. 19, 2292-2302. doi: $10.2174 / 092986712800229014$

Percival, R. S., Devine, D. A., Duggal, M. S., Chartron, S., and Marsh, P. D. (2006). The effect of cocoa polyphenols on the growth, metabolism, and biofilm formation by Streptococcus mutans and Streptococcus sanguinis. Eur. J. Oral Sci. 114, 343-348. doi: 10.1111/j.1600-0722.2006.00386.x

Pereira, J. V., Bergamo, D. C., Pereira, J. O., França Sde, C., Pietro, R. C., and SilvaSousa, Y. T. (2005). Antimicrobial activity of Arctium lappa constituents against microorganisms commonly found in endodontic infections. Braz. Dent. J. 16, 192-196. doi: 10.1590/S0103-64402005000300004

Ramakrishna, Y., Goda, H., Baliga, M. S., and Munshi, A. K. (2011). Decreasing cariogenic bacteria with a natural, alternative prevention therapy utilizing phytochemistry (plant extracts). J. Clin. Pediatr. Dent. 36, 55-63. doi: 10.17796/jcpd.36.1.f485870h90174311

Reygaert, W. C. (2014). The antimicrobial possibilities of green tea. Front. Microbiol. 5:434. doi: 10.3389/fmicb.2014.00434

Rôças, I. N., and Siqueira, J. F. Jr. (2013). Detection of antibiotic resistance genes in samples from acute and chronic endodontic infections and after treatment. Arch. Oral Biol. 58, 1123-1128. doi: 10.1016/j.archoralbio.2013. 03.010

Rukayadi, Y., and Hwang, J. K. (2006). Effect of coating the wells of a polystyrene microtiter plate with xanthorrhizol on the biofilm formation of Streptococcus mutans. J. Basic Microbiol. 46, 410-415. doi: 10.1002/jobm.200510088
Sakagami, H., Kishino, K., Kobayashi, M., Hashimoto, K., Iida, S., Shimetani, A., et al. (2009). Selective antibacterial and apoptosis-modulating activities of mastic. In Vivo 23, 215-223.

Sampaio, F. C., Pereira Mdo, S., Dias, C. S., Costa, V. C., Conde, N. C., and Buzalaf, M. A. (2009). In vitro antimicrobial activity of Caesalpinia ferrea Martius fruits against oral pathogens. J. Ethnopharmacol. 124, 289-294. doi: 10.1016/j.jep.2009.04.034

Shafiei, Z., Shuhairi, N. N., Md Fazly Shah Yap, N., Harry Sibungkil, C. A., and Latip, J. (2012). Antibacterial activity of Myristica fragrans against oral pathogens. Evid. Based Complement. Alternat. Med. 2012:825362. doi: $10.1155 / 2012 / 825362$

Sharma, A., Gupta, S., Sarethy, I. P., Dang, S., and Gabrani, R. (2012). Green tea extract: possible mechanism and antibacterial activity on skin pathogens. Food Chem. 135, 672-675. doi: 10.1016/j.foodchem.2012.04.143

Shetty, S., Thomas, B., Shetty, V., Bhandary, R., and Shetty, R. M. (2013). An in-vitro evaluation of the efficacy of garlic extract as an antimicrobial agent on periodontal pathogens: a microbiological study. Ayu 34, 445-451. doi: 10.4103/0974-8520.127732

Shinada, K., Tagashira, M., Watanabe, H., Sopapornamorn, P., Kanayama, A., Kanda, T., et al. (2007). Hop bract polyphenols reduced three-day dental plaque regrowth. J. Dent. Res. 86, 848-851. doi: 10.1177/154405910708600908

Signoretto, C., Canepari, P., Stauder, M., Vezzulli, L., and Pruzzo, C. (2012). Functional foods and strategies contrasting bacterial adhesion. Curr. Opin. Biotechnol. 23, 160-167. doi: 10.1016/j.copbio.2011.08.006

Smith, K., Robertson, D. P., Lappin, D. F., and Ramage, G. (2013). Commercial mouthwashes are ineffective against oral MRSA biofilms. Oral Surg. Oral Med. Oral Pathol. Oral Radiol. 115, 624-629. doi: 10.1016/j.oooo.2012.12.014

Sofrata, A., Lingström, P., Baljoon, M., and Gustafsson, A. (2007). The effect of miswak extract on plaque $\mathrm{pH}$. An in vivo study. Caries Res. 41, 451-454. doi: $10.1159 / 000107931$

Sofrata, A., Santangelo, E. M., Azeem, M., Borg-Karlson, A. K., Gustafsson, A., and Pütsep, K. (2011). Benzyl isothiocyanate, a major component from the roots of Salvadora persica is highly active against Gram-negative bacteria. PLoS ONE 6:e23045. doi: 10.1371/journal.pone.0023045

Steinberg, D., Feldman, M., Ofek, I., and Weiss, E. I. (2004). Effect of a highmolecular-weight component of cranberry on constituents of dental biofilm. J. Antimicrob. Chemother. 54, 86-89. doi: 10.1093/jac/dkh254

Süntar, I., Oyardi, O., Akkol, E. K., and Ozcelik, B. (2015). Antimicrobial effect of the extracts from Hypericum perforatum against oral bacteria and biofilm formation. Pharm. Biol. doi: 10.3109/13880209.2015.1102948. [Epub ahead of print].

Thimothe, J., Bonsi, I. A., Padilla-Zakour, O. I., and Koo, H. (2007). Chemical characterization of red wine grape (Vitis vinifera and Vitis interspecific hybrids) and pomace phenolic extracts and their biological activity against Streptococcus mutans. J. Agric. Food Chem. 55, 10200-10207. doi: 10.1021/jf0722405

van Loveren, C., Broukal, Z., and Oganessian, E. (2012). Functional foods/ingredients and dental caries. Eur. J. Nutr. 51(Suppl. 2), S15-S25. doi: 10.1007/s00394-012-0323-7

Villinski, J. R., Bergeron, C., Cannistra, J. C., Gloer, J. B., Coleman, C. M., Ferreira, D., et al. (2014). Pyrano-isoflavans from Glycyrrhiza uralensis with antibacterial activity against Streptococcus mutans and Porphyromonas gingivalis. J. Nat. Prod. 77, 521-526. doi: 10.1021/np400788r

Welin-Neilands, J., and Svensäter, G. (2007). Acid tolerance of biofilm cells of Streptococcus mutans. Appl. Environ. Microbiol. 73, 5633-5638. doi: 10.1128/AEM.01049-07

Wolinsky, L. E., Mania, S., Nachnani, S., and Ling, S. (1996). The inhibiting effect of aqueous Azadirachta indica (Neem) extract upon bacterial properties influencing in vitro plaque formation. J. Dent. Res. 75, 816-822. doi: $10.1177 / 00220345960750021301$

Xie, Q., Li, J., and Zhou, X. (2008). Anticaries effect of compounds extracted from Galla chinensis in a multispecies biofilm model. Oral Microbiol. Immunol. 23, 459-465. doi: 10.1111/j.1399-302X.2008.00450.x

Yamanaka, A., Kimizuka, R., Kato, T., and Okuda, K. (2004). Inhibitory effects of cranberry juice on attachment of oral streptococci and biofilm formation. Oral Microbiol. Immunol. 19, 150-154. doi: 10.1111/j.0902-0055.2004. 00130.x

Yamanaka, A., Kouchi, T., Kasai, K., Kato, T., Ishihara, K., and Okuda, K. (2007). Inhibitory effect of cranberry polyphenol on biofilm formation and cysteine 
proteases of Porphyromonas gingivalis. J. Periodont. Res. 42, 589-592. doi: 10.1111/j.1600-0765.2007.00982.x

Yamanaka-Okada, A., Sato, E., Kouchi, T., Kimizuka, R., Kato, T., and Okuda, K. (2008). Inhibitory effect of cranberry polyphenol on cariogenic bacteria. Bull. Tokyo Dent. Coll. 49, 107-112. doi: 10.2209/tdcpublication.49.107

Yatsuda, R., Rosalen, P. L., Cury, J. A., Murata, R. M., Rehder, V. L., Melo, L. V., et al. (2005). Effects of Mikania genus plants on growth and cell adherence of mutans streptococci. J. Ethnopharmacol. 97, 183-189. doi: 10.1016/j.jep.2004.09.042

Yoo, S., Murata, R. M., and Duarte, S. (2011). Antimicrobial traits of tea- and cranberry-derived polyphenols against Streptococcus mutans. Caries Res. 45, 327-335. doi: 10.1159/000329181

Yoshinaga, Y., Ukai, T., Nakatsu, S., Kuramoto, A., Nagano, F., Yoshinaga, M., et al. (2014). Green tea extract inhibits the onset of periodontal destruction in rat experimental periodontitis. J. Periodont. Res. 49, 652-659. doi: $10.1111 /$ jre.12147

Conflict of Interest Statement: The authors declare that the research was conducted in the absence of any commercial or financial relationships that could be construed as a potential conflict of interest.

Copyright $\odot 2016$ Karygianni, Al-Ahmad, Argyropoulou, Hellwig, Anderson and Skaltsounis. This is an open-access article distributed under the terms of the Creative Commons Attribution License (CC BY). The use, distribution or reproduction in other forums is permitted, provided the original author(s) or licensor are credited and that the original publication in this journal is cited, in accordance with accepted academic practice. No use, distribution or reproduction is permitted which does not comply with these terms. 